University of Rhode Island

DigitalCommons@URI

Open Access Master's Theses

2002

\title{
Alternative Corrosion Coating- Their Effect and Influence on Adhesive Performance
}

Khaled Alawadhi

University of Rhode Island

Follow this and additional works at: https://digitalcommons.uri.edu/theses

\section{Recommended Citation}

Alawadhi, Khaled, "Alternative Corrosion Coating- Their Effect and Influence on Adhesive Performance" (2002). Open Access Master's Theses. Paper 991.

https://digitalcommons.uri.edu/theses/991

This Thesis is brought to you for free and open access by DigitalCommons@URI. It has been accepted for inclusion in Open Access Master's Theses by an authorized administrator of DigitalCommons@URI. For more information, please contact digitalcommons-group@uri.edu. 
ALTERNATIVE CORROSION COATING -THEIR EFFECT AND INFLUENCE ON ADHESIVE PERFORMANCE

BY

KHALED ALAWADHI

A THESIS SUBMITTED IN PARTIAL FULFILMENT OF THE REQUIREMENTS FOR THE DEGREE OF

MASTER OF SCIENCE

IN

OCEAN ENGINEERING

UNIVERSITY OF RHODE ISLAND

2002 
MASTER OF SCIENCE THESIS

OF

KHALID ALAWADHI

APPROVED:

Thesis Committee

Major Professor

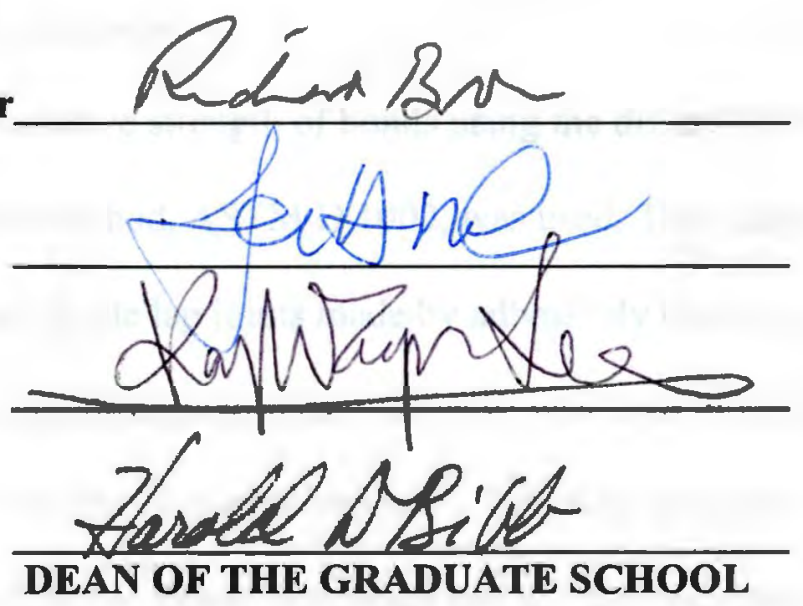

UNIVERSITY OF RHODE ISLAND

2002 


\section{Abstract}

The corrosion behavior of $\mathrm{Cr}_{2} \mathrm{O}_{3}$ and $\mathrm{TiO}_{2}$ based surface treatments in $0.5 \mathrm{~N}$ $\mathrm{NaCl}$ solution was investigated. These surface treatments are used for adhesive bonding of SS316L both to itself, other metals and non-metals. In order to quantify corrosion behavior and determine their ability to passivate in a chloride environment, a poteniodynamic test was employed.

To measure the adhesive strength of bonds using the different surface treatments, a standard test method, ASTM D 1002, was used. This measured the apparent shear strength of single lap joints made by adhesively bonding metals specimens together. A general-purpose epoxy adhesive was used in the experiments.

To investigate the effect of marine exposure, lap joints samples were placed in salt spray apparatus for different exposure periods and the residual shear strength measured. Results indicated that the shear strength of adhesive joints coated with $\mathrm{Cr}_{2} \mathrm{O}_{3}$ decreased in strength to a value less than joints treated with $\mathrm{TiO}_{2}$, even though the initial strength was higher.

Adhesive and cohesive failure of joints was noticed. In order to examine the surface conditions of the samples after failure, a scanning electron microscopy (SEM) was employed. The surface treatments did not change the surface features markedly.

It is suggested that the decrease in bond strength for the $\mathrm{Cr}_{2} \mathrm{O}_{3}$ treatment was due to crevice corrosion between the SS316 and the adhesive. The $\mathrm{TiO}_{2}$ treatment did not show the same degree of crevice corrosion. The potentiodynamic data supported 
this theory as the $\mathrm{Cr}_{2} \mathrm{O}_{3}$ treatment showed a tendency to localized corrosion while the $\mathrm{TiO}_{2}$ treatment did not. 


\section{ACKNOWLEDGEMENTS}

First and foremost, I would like to thank my thesis advisor, Professor Richard Brown, whose continuous guidance and constant encouragement made this work possible. I am grateful for Professor James Miller and Professor Kang-Won Wayne Lee for their review and comments towards my thesis and also Professor Stanley Barnett for agreeing to be the chairperson of my thesis defense committee. I appreciate the help of all my officemates and colleagues in their comments and assistance.I am extremely thankful for my family back home for their supporting and encouraging me as they endured putting me though college. May gad bless them and bless all of you and bless the whole world. 


\section{Preface}

This thesis is submitted in standard from according to the requirements set forth by the Graduate school of the university of Rhode island for submission of the thesis .All tables and micrographs were either computer generated or scanned images 
Abstract .ii

Acknowledgment.................................................................

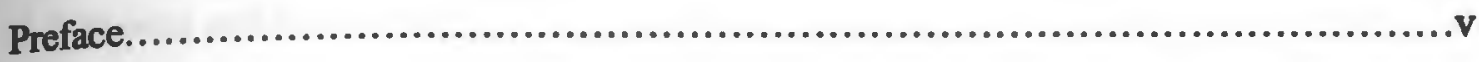

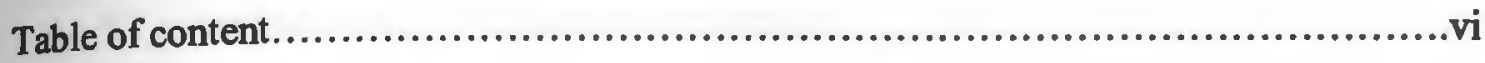

List of Tables .................................................................

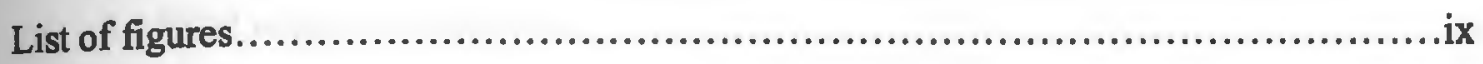

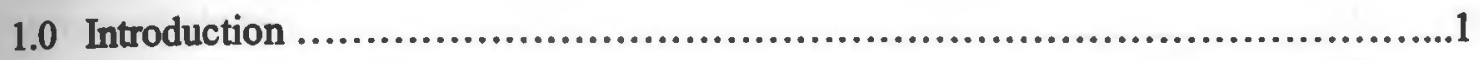

1.1 Corrosion..................................................................... 1

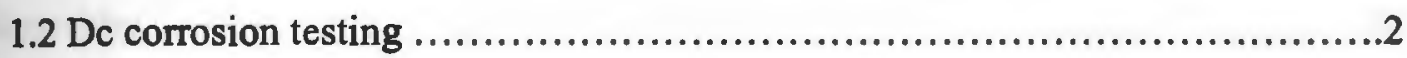

$1.3 \mathrm{Dc}$ corrosion testing techniques..........................................

1.4 Chromate conversion coating............................................ 4

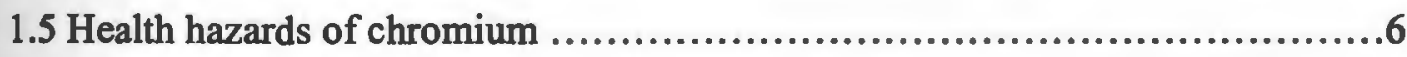

1.6 Titanium Dioxide coating ...............................................8

1.7 Adhesive bonding ..................................................... 10

1.8 Epoxies................................................................11

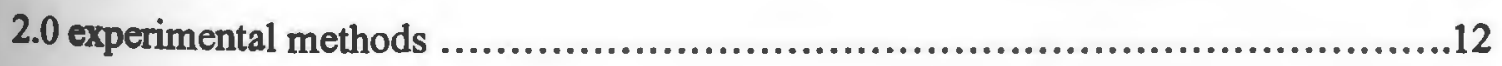

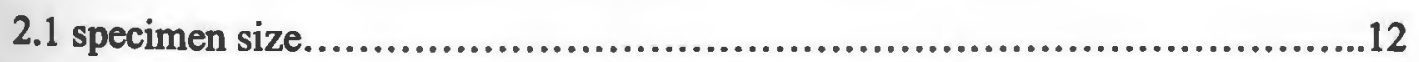

2.2 Coating of $316 \mathrm{LSS}$ by chromium Trioxide. .............................12

2.3 Coating of $316 \mathrm{Lss}$ by Titanium Dioxide.....................................13

2.4 potentiodynamic polarization method .......................................13 
2.5 cyclic polarization......................................................13

2.6 adhesive bonding techniques............................................

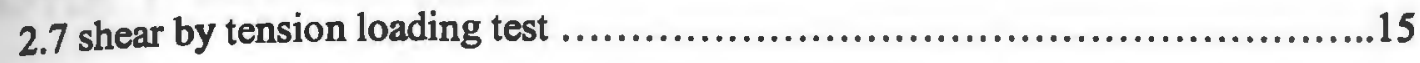

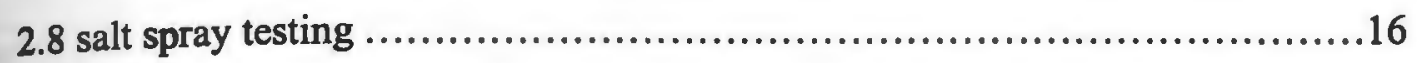

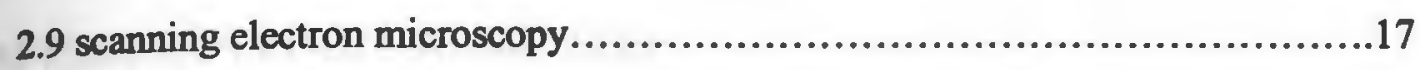

3.0 Results and discussion

3.1 potentiodynamic polarization experiment................................18

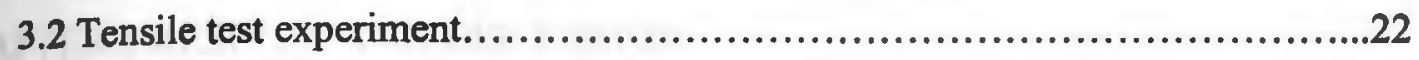

3.3 SEM examination test..................................................26

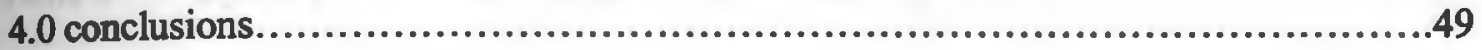

5.0

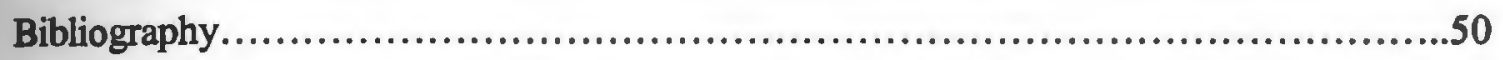




\section{LIST OF TABLES}

CHAPTER 1 INTRODUCTION:

None

CHAPTER 2 EXPERIMENTAL METHOD:

None

CHAPTER 3 RESULTS AND DISCUSSION:

Table 1 Cyclic polarization characteristics of bare SS 316

Table 2 Cyclic polarization characteristics of $\mathrm{TiO}_{2}$ and $\mathrm{CT}_{2} \mathrm{O}_{3}$ coating .30

Table 3 Data characteristics of tensile test for each bonded and coated SS 316L either by Titanium Dioxide or Chromium Trioxide ( 0.005 inch adhesive thickness

Table 4 Data characteristics of tensile test for bonded and non coated SS 316L (0.005 adhesive thickness). 31

Table 5 Data characteristics of tensile test for each bonded and coated SS 316L Either by Titanium Dioxide or Chromium Trioxide (0.01 inch adhesive thickness) .32

Table 6 Data characteristics of tensile test for bonded and non coated SS 316L (0.01 inch adhesive thickness). 


\section{LIST OF FIGURES}

Chapter 1 Introduction

None

Chapter 2 Experimental method

page

Figure 1 Potentiodynamic Polarization Curve for SS316L Non coated and exposed to de-aerated $0.5 \mathrm{M} \mathrm{NaCl}$ solution

Figure 2 Potentiodynamic Polarization Curve for SS316L coated by chromium trioxide and titanium dioxide exposed to de-aerated $0.5 \mathrm{M} \mathrm{NaCl}$ solution

Figure 3 Comparison of failure load for the two pairs of chromium trioxide coated samples and another two pairs of titanium dioxide coated samples that were exposed to salt spray test for one week with adhesive thickness of 0.005 inch

Figure 4 Comparison of failure load for the two pairs of chromium trioxide coated samples and another two pairs of titanium dioxide coated samples that were exposed to salt spray test for two week with adhesive thickness of 0.005 inch. 
Figure 5 Comparison of failure load for the two pairs of chromium trioxide coated samples and another two pairs of titanium dioxide coated samples that were exposed to salt spray test for three weeks with adhesive thickness of 0.005 inch.

Figure 6 Comparison of failure load for the two pairs of chromium trioxide coated samples and another two pairs of titanium dioxide coated samples that were exposed to salt spray test for four weeks with adhesive thickness of 0.005 inch.

Figure 7 Comparison of failure load for the two pairs of chromium trioxide coated samples and another two pairs of titanium dioxide coated samples that were exposed to salt spray test for five weeks with adhesive thickness of 0.005 inch.

Figure 8 Comparison of failure load for the two pairs of chromium trioxide coated samples and another two pairs of titanium dioxide coated samples that were exposed to salt spray test for one week with adhesive thickness of 0.01 inch. .38 
Figure 9 Comparison of failure load for the two pairs of chromium trioxide coated samples and another two pairs of titanium dioxide coated samples that were exposed to salt spray test for two weeks with adhesive thickness of 0.01 inch.

Figure 10 Comparison of failure load for the two pairs of chromium trioxide coated samples and another two pairs of titanium dioxide coated samples that were exposed to salt spray test for three weeks with adhesive thickness of 0.01 inch

Figure 11 Comparison of failure load for the two pairs of chromium trioxide coated samples and another two pairs of titanium dioxide coated samples that were exposed to salt spray test for four weeks with adhesive thickness of 0.01 inch

Figure 12 Comparison of failure load for the two pairs of chromium trioxide coated samples and another two pairs of titanium dioxide coated samples that were exposed to salt spray test for five weeks with adhesive thickness of 0.01 inch

Figure 13 Average failure load for all coated samples either by trioxide chromium or titanium dioxide exposed to salt spray test on weekly bases with adhesive thickness of 0.005 inch. 
Figure 14 Average failure load for all coated samples either by trioxide chromium or titanium dioxide exposed to salt spray test on weekly bases with adhesive thickness of 0.01 inch

Figure 15 Comparison of failure load between uncoated reference samples after air exposure for five weeks then, with adhesive thickness of 0.005 inch

Figure 16 Comparison of failure load between uncoated reference samples after air exposure for five weeks, adhesive thickness of 0.01 inch

Figures 17 Comparison of failure load for non coated 316L samples after air exposure

for 5 weeks, 0.005 inch adhesive thickness.

Figure 18 Comparison of failure load for non coated 316L samples after air exposure

for 5 weeks, 0.01 inch adhesive thickness.

Figures 19 Corrosion on the chromate sample took place after 5 weeks exposure to salt spray. 44

Figure 20 Crevice corrosion on $316 \mathrm{~L}$ 


\section{CHAPTER I \\ INTRODUCTION}

\subsection{CORROSION:}

Corrosion is a spontaneous process of returning metals to their natural state by oxidation and reduction reactions, which can result in loss of structural integrity. Stainless steels are a group of metallic alloys known for their high resistance to corrosion..$^{1}$ Stainless steel can be divided into several types and can have different properties depending on the alloy composition of each type. One of the major factors determining whether pitting or crevice corrosion will occur is the chromium, molybdenum, and nitrogen content of the stainless steel . ${ }^{2}$

Corrosion of stainless steel can be initiated by exposure to seawater.Two processes occur upon immersion of a stainless steel in natural seawater, both of which displace the corrosion potential in the noble direction. Firstly, during the readjustment process, the air-formed passive film on the stainless steel adjusts its chemical composition and becomes thicker. Secondly, a biofilm develops on top of the passive film. This biofilm formation is also known as a " natural population biofilm" because it comprises of a variety of bacteria and algae. These films also raise the corrosion potential above the pitting potential for type 304 and type 316 stainless steel.$^{3}$

Crevice corrosion is a localized type of corrosive attack. It occurs when a small crevice is formed between a metal and a non-metal in the presence of an aggressive environment. If the metal is susceptible under these conditions, then crevice corrosion will occur. This is highly probable in a lap joint under marine exposure. Analogous to pitting, crevice corrosion will occur when the metal potential equals or exceeds the 
crevice corrosion potential . Since this value is usually less noble than pitting potentials, crevice corrosion will usually occur before pitting, and the corroding area may in fact prevent pitting by acting as a sacrificial anode. For stainless steel in seawater, crevice corrosion is considered to be a more serious corrosion problem than pitting .

Unfortunately, crevice corrosion potentials vary with crevice geometry and therefore are not useful for alloy or environment comparisons. Crevice corrosion comparisons are generally made based on the severity of corrosive attack or the presence or absence of corrosive attack .

The last two decades have seen an increase in the use of electrochemical techniques to the study the corrosion behavior of stainless steels. This increase has been stimulated by the desire to develop the ability to predict by short-term laboratory tests, the behavior of stainless steel in industrial and natural environments . Corrosion recently has become a fairly popular subject in the adhesives engineering area. Much of the investigative work has been in the direction of adhesively bonded structures resistant to specific corrosive environments . There is still a need, however to emphasize strongly the potential dangers for adhesive bonds as a result of crevice corrosion, the most important being decrease in strength or load carrying ability .

\subsection{CORROSION TESTING:}

DC electrochemical tests involve applying a potential to a specimen immersed in an electrolyte and measuring the resulting current. Since corrosion is an electrochemical reaction, a quantitative corrosion rate can be determined. Anodic oxidation of the metal results in corrosion and can be expressed by the general half cell reaction :- 


$$
M->M^{n+}+n e^{-}
$$

Like wise a cathodic reduction reaction takes place at the same rate as oxidation, which completes the circuit. The unit of measure of current is Ampere, which is equivalent to a current of $208,200,000$ electrons per second . The measured current density, current per unit area, is directly proportional to the flux of electrons or the corrosion rate for a particular material. By varying the applied potential of the anodic and cathodic reactions and measuring the current density, $\mathrm{E}_{\mathrm{oc}}$, the open circuit potential when the reaction changes from anodic to cathodic and there is no current measured, can be determined .

Some materials, under certain environmental conditions, experience a significant reduction of the corrosion rate caused by the formation of an adherent protective film on the surface. This phenomenon is called passivity. A materials passive region can be determined by continuing to apply increasing anodic potentials from $\mathrm{E}_{\mathrm{oc}}$ until the current density reaches a peak and then decrease to a considerably lower value. This peak is called the Primary Passivating Potential $\left(\mathrm{E}_{\mathrm{PP}}\right)$. This is the beginning of the passive region. As the potential increases in the anodic direction, current density will remain low until a rapid increase occurs. This is called the Transpassive region and is due to the dissolution of the passive film layer. The potential at this point is called the Transpassive ( $\mathrm{E}_{\mathrm{TP}}$ ). If the potential is increased well into the transpassive region and allowed to reverse to a lower potential, the ability of the passivating material to resist localized, pitting or crevice, corrosion may be determined. If upon reversing the potential, moving in a cathodic direction, the current either follows or decreases faster than the forward scan , then any damage to the passive film will be repaired 
Immediately. This material would be considered to have a good localized corrosion resistance ${ }^{4}$ Alternatively, upon reversing potential the current is greater than the forward scan, then the material has a poor resistance to localized corrosion.

\subsection{CORROSION TESTING TECHNIQUES:}

The basic equipment and experimental procedures used for potetiodynamic anodic polarization scans is described in ASTM G5. The counter electrode was a high density high purity, graphite rod which is a commonly used alternate to the ASTM suggested platinum electrode. ASTM maximum recommended scan rate of $0.6 \mathrm{~V} / \mathrm{hr}$ was reduced to a more conservative $0.1 \mathrm{mV} / \mathrm{sec}$. Scans began at $125 \mathrm{mV}$ below, or more cathodic, than $\mathrm{E}_{\mathrm{oc}}$ and moved in the anodic direction. The scan direction was reversed to cathodic when the potential reached $200 \mathrm{mV}$ above $\mathrm{E}_{\mathrm{oc}}$ as long as the current density was at least $200 \mathrm{uA} / \mathrm{cm} 2$. The ASTM procedure specifies the scan to reverse at $5000 \mathrm{uA} / \mathrm{cm} 2$. The ASTM required the scan to continue until the hysteresis loop close or until corrosion potential is reached $100 \mathrm{mV}$ above $E_{\text {corr }}$. This allowed automatic testing that identified all the pertinent data points .

\subsection{CHROMATE CONVERSION COATING:}

Conversion coating is any coating that chemically changes the surface of a metallic part. Conversion coatings serve two purposes, firstly corrosion protection and secondly assuring good adhesion of the coated surface to other materials such as paint and adhesives. There are two main conversion treatments that have been used in this project, coating by chromium trioxide or by titanium dioxide. Before applying the conversion coating the surface must be degreased in either acid or alkali degreasers and, after coating application, rinsed and dried . Conversion coatings can be applied either 
by immersion or spraying. Spraying equipment will result in higher investments and some parts of a complicated structure may be difficult to treat properly. ${ }^{5}$ On the other hand, the immersion treating of certain geometry's can cause drag out or carryover of the chemicals which can cause cross contamination of the process chemicals thereby reducing their active life. The choice between spray and immersion must be done after a total evaluation of the economy of the process and the quality of the coating . Chromate conversion coating has two main benefits ; one of them is that the mixed romium/substrate metal oxide coating provides better corrosion resistance than the substrate metal oxide alone. Additional corrosion protection is provided by chromate ions entrapped in the coating. These ions are readily leached from the coating and act as corrosion inhibitors. Another property of the chromate coating is its ability to improve the adhesion of paint ${ }^{6}$. This is probably related to the cellular structure of the mixed oxide film, which provides a base with more attachment points .

Chromate conversion coating is produced on various metals by chemical treatment with mixtures of hexavalent chromium and certain other compounds. These treatments convert the metal surface to a superficial layer containing a complex mixture of chromium compounds. The coating is usually applied by immersion, although apraying, brushing, swabbing or electrolytic methods are also used. A number of metals and their alloys can be treated, notably: aluminum, cadmium, copper, magnesium, silver and zinc ${ }^{7}$. It was found that they have many useful applications in the aircraft, 2erospace, welding, etching and steel manufacturing industries . The chromate films in most common use are formed by the chemical reaction of hexavalent chromium with a metal surface in the presence of other components, or activators in acid solution. The 
hexavalent chromium is partially reduced to trivalent chromium during the reaction, with a concurrent rise in $\mathrm{pH}$, forming a complex mixture consisting largely of hydrated basic chromium chromate and hydrous oxides of both chromium and the basic metal. The composition of the film is rather indefinite, since it contains varying quantities of the reactants, reaction products and water of hydration, as well as the associated ions of the particular systems. There are many important factors that control the formation of the chromate film. One of those factors is the $\mathrm{pH}$ of the treatment solution. For any given metal/chromate solution system there will exit a $\mathrm{pH}$ at which the rate of coating formation is maximum. As the $\mathrm{pH}$ is lowered from this point, the reaction products become more soluble, tending to remain in solution rather than deposit as a coating on the metal surface. Even though the rate of metal dissolution increases, the coating thickness will remain low. Increasing the $\mathrm{pH}$ beyond the maximum gradually lower the rate of metal dissolution and coating formation to the point at which the reaction, for all practical purposes, ceases. Another factor that controls the film formation is the activator. Chromate films will not form without the present of certain anions in regulated amount. They are commonly referred to as "activators" and include acetate, anions such as acetate, format, chloride, fluoride, nitrate phosphate and sulfamate. The character, rate of formation and properties of chromate films vary with the particular activator and its concentration. In addition to the chemical makeup of the chromating solutions three more parameters that should be considered during film formation. One of the factors is treatment time, immersion time or contact time of the metal surface and the solution. This can vary from one second to one hour, depending on the solution being used and metal being treated. Another factor is the solution temperature. 
Chromating temperature varies from ambient to boiling, depending on the particular solution and the metal being processed. For a given system, an increase in the solution temperature will accelerate both the film forming rate and the rate of attack on the metal surface. This can result in a change in the character of the chromate film. Thus, temperature should be adequately maintained to insure consistent results. Solution agitation is another factor that affect the chromate film formation. Agitation of the working solution, or movement of the work in the solution, generally speeds the reaction and provides for more uniform film formation. Air agitation and spray installation have been used for this purpose .

\subsection{HEALTH HAZARDS OF CHROMIUM:}

Chromium can enter the body when people breath air, eat food, or drink water containing it. Chromium is also found in house dust and soil, which can be ingested or inhaled. Of the various forms of chromium, hexavalent chromium is the most toxic. Certain hexavalent chromium compounds have been found to be carcinogenic in humans, but the evidence to date indicates that the carcinogenicity is site-specific-limited to the lung and sinonasal cavity--and dependent on high exposures, such as might be encountered in an industrial setting. Hexavalent chromium can cause a wide range of other health effects. Inhaling relatively high concentrations of some forms of hexavalent chromium can cause a runny nose, sneezing, itching, nosebleeds, ulcers, and holes in the nasal septum. Short-term high-level inhalation exposure can cause adverse effects at the contact site, including ulcers, irritation of the nasal mucosa, and holes in the nasal septum. Ingestion of very high doses of hexavalent chromium can cause bidney and liver damage, nausea, and irritation of the gastrointestinal tract, stomach 
ulcers, convulsions, and death. ${ }^{5}$ Dermal exposures may cause skin ulcers or allergic reactions. Hexavalent chromium is one of the most highly allergenic metals (second only to nickel). Studies of mice fed high doses of hexavalent chromium have shown aproductive effects including reduced litter size and decreased fetal weight. There is a great deal of controversy about the relative health effects of the various routes of exposure for hexavalent chromium. According to the International Agency for Research on Cancer (IARC), ingested hexavalent chromium is largely converted to trivalent chromium in the stomach, a fact that many chromium experts believe prevents ingestional exposures from posing significant health dangers, since trivalent chromium is not readily absorbed into the body. ${ }^{5}$ The saliva, gastric juice, intestinal bacteria, blood, liver, epithelial lining fluid, pulmonary alveolar macrophages, peripheral lung parynchema, and bronchial tree have all been associated with eliminating hexavalent chromium from the body. In an article published in the March 1997 issue of quanogenesis, Silvio De Flora, director of the Department of Health Sciences at the University of Genoa, and colleagues present estimates of the ability of various human organs, cell populations, and fluids to reduce hexavalent chromium in the body. ${ }^{5}$ They found that major detoxification is accomplished by red blood cells, with over half of a 100-microgram $(\mu \mathrm{g})$ dose of hexavalent chromium being sequestered or reduced by 1 milliliter of blood within 60 minutes. De Flora and colleagues write, "The massive reducing and sequestering capacity of the blood explains why hexavalent chromium exerts its toxicological consequences at the portal of entry into the organism, while it is not a systemic toxicant or carcinogen" ? 


\subsection{TITANIUM DIOXIDE COATING:}

The high corrosion resistance and good biocompatibility of titanium and its alloys are dure to a thin passive film that consists essentially of titanium dioxide. There is increasing evidence, however, that under certain conditions extensive titanium release may occur in vivo. An ion beam assisted sputtering deposition technique deposited thick and dense $\mathrm{TiO}_{2}$ film on titanium and stainless steel surfaces. Titanium films have been investigated in phosphate buffered saline solution using the following measurements: (1) open circuit potential versus time of exposure, (2) electrochemical impedance pectroscopy, (3) potentiodynamic polarization, and (4) Mott-Schottky plot. ${ }^{8}$ A higher electrical film resistance, lower passive current density, and lower donor density have been measured for sputter-deposited oxide film on titanium. The improved corrosion protection of the sputter-deposited oxide film can be explained by a low defect concentration and, consequently, by a slow mass transport process across the film. As opposed to $\mathrm{TiO}_{2}$ on titanium, a deviation from normal $n$-type semiconducting MottSchottky behavior was observed for $\mathrm{TiO}_{2}$ on stainless steel. ${ }^{9}$ In 1994 Imokawa, Fujisawa, Suda and Tsuikawa studied the protection of 304 stainless steel by titanium dioxide.

The photo electrochemical behavior of 304 stainless steel sputter coated with $\mathrm{TiO}_{2}$ in $\mathrm{NaCl}$ solutions at ambient temperature was studied. ${ }^{15}$ It was found that coating the 304 with a $\mathrm{TiO}_{2}$ thickness greater than $3 \mathrm{~nm}$ initiated cathodic protection under light irradiation condition through the $\mathrm{TiO}_{2}$ coating layer acting as a non-sacrificial anode. Up to a $\mathrm{TiO}_{2}$ coating thickness of $100 \mathrm{~nm}, \mathrm{E}_{\mathrm{oc}}$, the open circuit potential of the coated steel specimen tended to shift toward the less noble, cathodic, values with increasing 
coating layer thickness. $E_{o c}$ of the coating steel specimen with thickness $100 \mathrm{~nm}$ was $340 \mathrm{~m}$ V vs. SCE under the light irradiation condition ensuring no occurrence of crevice corrosion in $\mathrm{NaCl}$ solution with concentration not exceeding $2 \%$. When defects were present in the coating layer, $\mathrm{E}_{\mathrm{oc}}$ remained constant as long as the area ratio was no greater than $10 \%$. With rising intensity of the irradiated light, $E_{o c}$ of the coated steel specimen tended to shift toward less noble side implying enhanced trend of cathodic corrosion protection. A possible cause of ennoblement of $\mathrm{E}_{o c}$ for the coated steel pecimen subjected to heat treatment at temperature higher than $300^{\circ} \mathrm{C}$ under light irradiation condition was identified to be the diffusion of $\mathrm{Fe}$ from the steel substrate to the $\mathrm{TiO}_{2}$ coating layer .

As results of these results, it was confirmed that coating from 30 to $100 \mathrm{~nm}$ thick could protect 304 stainless steel cathodically under illumination. The coating defects don't hinder the protection performance when its area ratio is less than 1/10. As shown by Honda and Fujishima, the anodic reaction on $\mathrm{TiO}_{2}$ is neither dissolution nor todecomposition but oxygen evolution. Therefore, the $\mathrm{TiO}_{2}$ coating is expected to work as a non-sacrificed anode. This is a highly contrasted feature of the coating as compared with zinc coating for steels, which is destined to be consumed. $\mathrm{TiO}_{2}$ thick films were prepared on stainless steel by plasma-spray coating and the electrode potential of the films were reduced by about $250 \mathrm{mV}$ under ultra-violet irradiation. This potential drop value is sufficient for protection from corrosion.$^{16}$

Cathodic protection for stainless steel 304L was studied by sol-gel- derived $\mathrm{TiO}_{2}$ coating under illumination of light and they found out that Fe was much more intense than other elements, which decrease the photo effect of $\mathrm{TiO}_{2}$ coating. In order to avoid 
Feirvolvement in the coating, a passivation treatment with $\mathrm{HNO}_{3}$ was carried out to retard the $\mathrm{Fe}$ by enrichment of $\mathrm{Cr}$ in the passive film, and enabled the $\mathrm{TiO}_{2}$ coating on the 304 specimens to exhibit less noble photo potentials when temperature reached $400 \mathrm{C} .^{17}$

\subsection{ADHESIVE BONDING:}

Adhesive bonding has been used for a number of decades for construction of aircraft components. Lightweight sandwich construction and structural bonded joints form a major proportion of modern aircraft. Bonded patches are also used for repair of andwich panels, cracks in metallic structure or reinforcement of deficient structures. The advantages of adhesive bonding include reduced weight, high performance at low cost, electrical insulation of materials which minimize the possibility of electrolytic corrosion, longer life in the presence of structure vibration and distribution of stress over an area, not a confined point. ${ }^{17}$ The main disadvantage is that it does not permit visual examination of the bonded area. The appropriateness for adhesive bonding depends on surface preparation and bonding design, along with the function to be performed by the adhesive joint.

A simple lap joint is the most common for structural elements because of its simplicity, and low cost. Increasing the width of the joint results in a proportional increase in strength while increasing the height beyond a certain limit has very little effect at all.$^{18}$ The mechanical load imposed on the joint is shear loading which is perpendicular to the bond line. The end of the bond resists a greater amount of stress than does the middle. If the overlapping length is greatly increased, there is little, if any, change in the bond strength. There are two main failure modes, adhesive failure which 
is a bond failure between the adhesive and the adherend and cohesive failure when a fracture occurs within the adhesive and allows a layer of the adhesive to remain on both surfaces .

Corrosion at any site within a lap joint depends on various factors such us solution resistance, alloy composition, solution chemistry, presence of crevices and local potential. An extensive investigation of the corrosion behavior due to adhesive on coated steel samples with an interlayer between the adhesive and the substrate was performed. A Ti interlayer was introduced to form TiN/Ti/steel. Results demonstrated that the corrosion properties of the TiN coated steel are determined by a synergetic effect between the defect content and thickness of the coating. The strength of the

coated samples increases with increasing interdiffusion layer thickness. ${ }^{23,24,25,26,27,28}$

\subsection{EPOXIES:}

Epoxy adhesives provide a strong joint and because of their excellent creep properties they are suitable for structural application and for metal bonding, glass, ceramics, concrete and thermosetting plastic. Epoxies can be found in many different types of compositions. The mechanics of the adhesive can be divided in to three groups (1) chemical bonding, (2) physical bonding, (3) mechanical interlocking. ${ }^{25}$

\subsection{OBJECTIVE:}

The objective of this study is to measure the residual lap shear strength of thesively bonded 316L stainless steel after marine exposure. Different surface treatments will be used prior to adhesive bonding, the normal chromate based and an alternate to chromate. The data will determine the effectiveness of an alternate to chromate. 


\section{CHAPTER II}

\section{EXPERIMENTAL METHODS}

The material used in this study is stainless steel $316 \mathrm{~L} .316 \mathrm{~L}$ is known for its low carbon content, the composition of this type of stainless steel is $16-18 \%$ chromium, $10-14 \%$ nickel, $0.03 \%$ carbon, $2.0 \%$ molybdenum, $1.0 \%$ silicon, 0.045 phosphate and $0.03 \%$ sulfur.316 type of stainless steel contains molybdenum and has greater resistance to pitting in marine and chemical industry environment. The low carbon content is for weldability to avoid weld decay .

\subsection{SPECIMEN SIZE:}

The measurements of the specimen used in this work were as follows: the length was $75 \mathrm{~mm}$, the width was $25 \mathrm{~mm}$, and the thickness was $1.6 \mathrm{~mm}$.

\subsection{COATING OF 316L BY CHROMIUM TRIOXIDE:}

To etch the metal it was immersed for approximately three quarter of their length in a bath consisting of 25 grams of sodium metasilicate, 11 grams of tetrasodium pyrophosphate, 11 grams of sodium hydroxide, 3 grams of nacconol dissolved in $950 \mathrm{cc}$ of deionized water DI for 10 minutes at desired temperature of 140$160 \mathrm{~F}$ with a circulating system operation. The sample was rinsed with deionized water (DI) before immersion in a second bath of 100 grams of chromium trioxide dissolved in 500 grams of DI for another 10 minutes at $140-190 \mathrm{~F}$. The metal was washed in cold running DI as prolonged rinsing or use of very hot rinse water can dissolve, or leach the more soluble hexavalent chromium compound from a freshly formed coating resulting in a decrease in protective value. During rinsing the metal plane was parallel to the flow 
of the solution. A final drying took place in a forced-draft oven at less than $140 \mathrm{~F}$, then the sample was allowed to air cool .

After the cooling, adhesive was applied to some of the specimens using the standard method while some of the cooled specimens were tested electrochemically.

\subsection{COATING OF 316L BY TITANIUM DIOXIDE:}

For the alternate to chromate, the only change was to replace chromium dioxide with titanium dioxide so the bath consisted of 50 grams of titanium dioxide dissolved in $500 \mathrm{cc}$ DI for 10 minutes at $140-190 \mathrm{~F}$. The remainder of the coating process was identical to that used for chromium dioxide.

\subsection{POTENTIODYNAMIC POLARIZATION METHODS:}

Polarization methods such as potentiodynamic polarization, potentiostaircase, and cyclic voltammetry are often used for laboratory corrosion testing. These techniques can provide significant useful information regarding the corrosion mechanisms, corrosion rate and susceptibility of specific materials to corrosion in designated environment. Polarization methods involve changing the potential of the working electrode and monitoring the current, which is produced as a function of time or potential.

\subsection{CYCLIC POLARIZATION:}

The advantage of cyclic potentiodynamic anodic polarization scans is quick results and easily interpreted date. The disadvantages of this test are the data cannot predict long-term behavior; it is a destructive test; and it cannot be used in certain high resistance applications. 
The localized corrosion behavior of the specimens was investigated by cyclic alarization. The parameters used for cyclic polarization measurements were: initial potential $=-125 \mathrm{mV}$ for OCP, maximum potential $=400 \mathrm{mV}$ for OCP. Threshold value $=0.1 \mathrm{~mA}$, scan rate $=0.1 \mathrm{mV} / \mathrm{s}$ and the scan increment $=2.0 \mathrm{mV}$. When a cyclic anodic plarization curve is used several important parameters were obtained: $\mathrm{E}_{\mathrm{TP}}$ transpassive potential, $\mathrm{E}_{\mathrm{N}}$ pit nucleation potential and $\mathrm{E}_{\mathrm{P}}$ pit passive potential. A cyclic anodic polarization scan consists of two parts: the forward scan and the reverse scan. During the forward scan the pit nucleation potential $\mathrm{E}_{\mathrm{N}}$ or transpassivation potential $\mathrm{E}_{\mathrm{TP}}$ would be determined. The reverse scan yield a pit passivation potential $E_{P}$.

The electrochemical test was performed using an EG\&G Princeton Applied Research electrochemical system consisting of a model $273 \mathrm{~A}$ potentiostat and a computer with control software. A flat sample holder corrosion cell was used which contained platinum wire as a counter electrode and a saturated calomel electrode (SCE) reference electrode. The sample whose anodic behavior was investigated serve as the working electrode. To ensure a maximum cathodic reaction, oxygen was purged into the 0.5 normal sodium chloride electrolyte.

\subsection{ADHESIVE BONDING TECHNIQUES:}

Adhesion is one of the most complex and important parameters that determine the quality of coating systems. The theoretical adhesion strength is a result of all interfacial and intermolecular forces. However, the practical adhesion strength, which is the force or energy needed for detachment of the coating, never reaches this theoretical value. The difference is caused by the hollow spaces and defects at the interface of substrate and coating. The environment (temperature, diffusion of water, oxygen) contributes to 
the adhesive strength of a system, therefore, dry as well as wet adhesion are important parameters for characterization .

The procedure of adhesion bonding was as follows. A total of 48 lap shear test samples were prepared using 42 individual samples coated with chromium trioxide to make 21 lap shear test samples and 42 individual samples pairs coated with titanium dioxide to make 21 lap shear test samples, and 12 individual samples not coated and used to make 6 lap shear samples. The epoxy adhesive was applied to the area across the end of one or both metal sheets so that the adhesive would cover a space epproximately linch. The thickness of the adhesive layer was controlled by shims in the adhesive bonding fixture to be 0.01 or 0.005 inch. The assembled specimens were left for 24 hours at room temperature for the adhesive to cure.

\subsection{LAP JOINT TESTING:}

Lap joints were tested to failure in an Instron tensile test machine. The test is applicable for determining adhesive strength, surface preparation parameters and adhesive environmental durability. In this study the residual strength after marine exposure was measured.

For comparison, 3 non-coated specimens were tested to determine the lap joint strength in the absence of any surface coating. The rest of the specimens, both coated and the uncoated, were placed either in the open air or in the salt spray chamber. After a certain period of time, one week, 2 weeks, 3 weeks, or 4 weeks, the samples were withdrawn from the salt spray chamber or the open air tested to failure. The specimens were placed in the grip of the testing machine so that the outer $25 \mathrm{~mm}$ of each end were 
in contact with the jaws, and so that the long axis of the tested specimens coincided with the direction of the applied pull through the centerline of the grip assembly. The loading was applied immediately to the specimen at rate of $1200-1400$ psi of the shear area per minute. The loading was continued to failure. The rate of the loading was aproximated by free crosshead speed of $0.05 \mathrm{inch} / \mathrm{min}$. The loading at failure and the nature and the amount of this failure for each specimen was recorded.

\subsection{SALT SPRAY TESTING:}

The oldest and the most widely used test is ASTM B117, method for salt spray testing, a test that introduces a spray into a close chamber where some specimens are exposed at specific location and angles. The concentration of the $\mathrm{NaCl}$ solution was $5 \%$ by weight in deionized water. There is a wide range of chambers designs and sizes including walk- in rooms that are capable of performing this test.

Hot, humid air is created by bubbling compressed air through a bubble tower containing hot deionized water. Salt solution is typically moved from a reservoir through a filter to the nozzle by a gravity-feed system. When the hot, humid air and the salt solution mix at the nozzle, the solution is atomized into a corrosive atmosphere. This created a 100 percent relative humidity condition in the exposure zone. For a lowhumidity state the exposure zone of the chamber, air is forced into the exposure zone via a blower motor that directs air over the energized chamber heaters.

Specimens coated with paints or nonmetallic coating should not be cleaned or handled excessively prior to test. The specimens should be supported or suspended between $15-30^{\circ}$ from the vertical and parallel to the principal direction of flow of fog through the chamber, based upon the dominant surface being tested. The specimens 
should not contact each other or any metallic material or any material capable of acting as a wick. The salt solution should be prepared by dissolving $5 \pm 1$ parts by mass of sodium chloride in 95 parts of water. The salt used should be sodium chloride free of nickel and cooper and containing on the dry basis not more that $0.1 \%$ sodium iodide and not more than $0.3 \%$ of total impurities. The $\mathrm{pH}$ of the salt solution should be such that when atomized at $35^{\circ} \mathrm{C}$ the collected solution will be in the $\mathrm{pH}$ range from $6.5-7.2$. The compressed air supply to the nozzle or nozzle for atomizing the salt solution should be free of oil and dirt. The temperature should be maintained inside the chamber at 35 $+1.1-1.7^{\circ} \mathrm{C}$.

The test should be continuous for the duration of the entire test period.

Continuous operation implied that the chamber be closed and the spray operating continuously except for the short daily interruption necessary to inspect, rearrange, or remove test specimens to check and replenish the solution in the reservoir, and to make necessary recording. In this work 21 pairs coated with chromium trioxide were exposed to the salt spray for one week, two weeks, three weeks, four weeks and five weeks.

Another 21 pairs coated with titanium dioxide were exposed to the salt spay test for one week, two weeks, three weeks, four weeks and five weeks. After the exposure period, the samples were tested to failure.

\subsection{SCANNING ELECTRON MICRSOCOPY:}

Scanning electron microscopy was used to detail the surface appearance of the coating prior to and after failure. It provides direct image of the topographical nature of the surface from all the emitted secondary electrons. It helps investigate the mode of failure such as fatigue, creep, shear overload, tensile over load or other complex failure 
modes. The samples were scanned with a high energy electron beam in a raster pattern which causes the ejection of numbers of particles, including secondary electrons which form an image of the surface ejecting them. One disadvantage of the scanning electron microscope is that it is normally not possible to examine samples that produce any significant amount of vapor when placed in vacuum and many samples like grease and adhesive liquids, foods, gels cannot be examined. 


\section{CHAPTER III}

\section{RESULTS AND DISCUSSION}

\subsection{ELECTROCHEMICAL BEHAVIOR:}

A study of the electrochemical behavior of $\mathrm{TiO}_{2}$ and $\mathrm{Cr}_{2} \mathrm{O}_{3}$ coatings on $316 \mathrm{~L}$ stainless steel was conducted. The aggressive environment was $0.5 \mathrm{~N} \mathrm{NaCl}$. Cyclic polarization scans plots for bare $316 \mathrm{~L}$ is shown in figure (1). Upon reversal of the potential in a cathodic direction, the current density is higher than the forward anodic direction indicating that uncoated $316 \mathrm{~L}$ is susceptible to localized corrosion. A comparison of the cyclic polarization data for the $316 \mathrm{~L}$ coated by $\mathrm{TiO}_{2}$ and $\mathrm{Cr}_{2} \mathrm{O}_{3}$ is shown in figure (2). Data from these figures is shown in tables 1 and 2, listing the open circuit potential, the passivation potential, the critical current density and breakdown potential for passivation. The titanate coating has the same open circuit potential as the uncoated stainless steel, while the chromate coating is $100 \mathrm{mV}$ more anodic. Both of the coatings exhibit a passive region. However the chromate coating breaks down at less than $100 \mathrm{mV}$ anodic to its open circuit potential. The titanate coating does not break down over the same anodic shift from its open circuit potential. The chromate has a higher current density upon reversing the potential in the cathodic direction after breakdown, indicating that it would not resist localized corrosion. The titanate coating has a similar current density upon reversing the potential in the cathodic direction, indicating that it would have a good resistance to localized corrosion.

Earlier investigations have shown that for lower potential the surface films contains lower oxides state of components such as $\mathrm{Cr}^{3+}$, oxy hydroxide and small 
concentration of $\mathrm{Fe}^{3+}$, as well as an increased total content of oxide ${ }^{5}$. The formation of chromium oxides and iron oxides in the passive film because they are less noble than molybdenum and nickel. Passive films can be described by a three factor model : a hydrated layer in contact with solution, an oxide layer consisting of $\mathrm{Fe}$ and $\mathrm{Cr}$ oxides and a metallic layer enriched in $\mathrm{Ni}^{5}$. The current density increase above the transpassive potential was due to oxygen evolution and not rapid corrosion of the $316 \mathrm{~L}$. The passive film maybe formed by diffusion of the anions from metal surface through the passive film to the passive film / solution interface. The growth of the passive film is dependent on diffusion of various ionic species and or conductivity of the film. Therefore, as the passive film develops, the rate of the passive film formation decreases. The rate of the passive film formation slows enough that a gradual increase in open circuit potential with respect to time is observed as the passive film formation decreases. It is well known that either increasing the molybdenum content within the alloy or moving the applied potential in the active direction has a significant and beneficial effect on the resistance to breakdown of the passive film, especially for pitting corrosion by altering the distribution and the susceptibility of weak points in the passive film, with little change in the macro-characteristics of the film 5 . The cyclic polarization curves of $\mathrm{TiO}_{2} / \mathrm{ss}$ in figure (2) exhibited no hystersis. When this type of hystersis occurs the damaged passivity repair itself and pits do not initiate and the current density of the anodic back scan is either the same or less than the current density of the original forward anodic scan. The significant result obtained was that $\mathrm{TiO}_{2}$ coated $316 \mathrm{~L}$ has a greater passive range than $\mathrm{Cr}_{2} \mathrm{O}_{3}$ coated $316 \mathrm{~L}$ or bare metal and this is shown in figure 2. 


\subsection{ADHESIVE BONDING BEHAVIOR:}

Samples of coated and bonded $316 \mathrm{~L}$ with either $\mathrm{CrO}_{2}$ or $\mathrm{TiO}_{2}$ coatings were exposed to salt spray in from one to five weeks in order to determine the effect of a corrosive environment on the bond strength. ASTM standard B-117 was used and all samples were kept in the salt spray with constantly temperature of $95^{\circ} \mathrm{F}\left(35^{\circ} \mathrm{C}\right)$. Each specimen was tested until failure load was reached and recorded. Bond strength ranged from $200 \mathrm{lb}$ to $850 \mathrm{lb}$. Figures 3, 4, 5, 6, and 7 illustrate load failure in pounds versus time of exposure in weeks for four samples coated by $\mathrm{CrO}_{3}$ and $\mathrm{TiO}_{2}$ exposed in salt spray test for up to five weeks with adhesive thickness of $0.005 \mathrm{inch}$. The data showing failure load for the different exposures and surface coatings for 0.005 in adhesive thickness is presented in table 3. Data for uncoated and unexposed $316 \mathrm{~L}$ is shown in table 4. The chromate coating does increase the initial bond strength significantly, while the titanate coating has little effect on initial bond strength. The data indicates that the failure load decreases with exposure for both the $\mathrm{Cr}_{2} \mathrm{O}_{3}$ and $\mathrm{TiO}_{2}$ coated and bonded 316L exposed to salt. However the titanate showed a higher failure load compared to chromate coating after three weeks of exposure.

Figures $8,9,10,11$, and 12 illustrate the failure load for 4 pairs bonded and coated with $\mathrm{Cr}_{2} \mathrm{O}_{3}$ and $\mathrm{TiO}_{2}$ subjected to salt spray for up to five weeks with adhesive thickness of 0.01 inch. Failure loads as a function of exposure time in weeks are listed in table 5 for specimens with 0.01 inch adhesive thickness. Data for 0.01 in adhesive thickness $316 \mathrm{~L}$ but uncoated and unexposed is shown in table 6. Again chromate 
coating appeared to increase initial bond strength while the titanate had little effect. The failure load decreased for both coating types as exposure increased. However the titanate coating decreased less and was significantly higher than chromate after three weeks.

For both adhesive bond thickness, coating by $\mathrm{TiO}_{2}$ showed significantly higher bond failure load than $\mathrm{Cr}_{2} \mathrm{O}_{3}$ coated specimens after three weeks of exposure. Comparison of the date in table 3 and table 5 reveals an interesting point that thinner adhesive offered a higher degree of bond strength although there was an obvious decline in the load failure for all coated and bonded specimens either with 0.01 inch or 0.005 inch thickness. Comparison of the data in figures 13 and 14 illustrate the average failure load for all coated samples either by $\mathrm{Cr}_{2} \mathrm{O}_{3}$ or $\mathrm{TiO}_{2}$ and exposed to salt spray test on weekly basis with adhesive thickness of either 0.01 inch or 0.005 inch.

It is expected that localized corrosion due to the geometry from adhesive bonding occurred on the SS316L. Moisture adsorption might play a significant part in order to decrease the bonding strength, however this decrease should be the same for both coatings as the same adhesive and exposure conditions were used. Figure 15 and 16 shows a comparison between reference samples coated by $\mathrm{Cr}_{2} \mathrm{O}_{3}$ and $\mathrm{TiO}_{2}$ after five weeks with two different adhesive thickness after five weeks of air exposure. An insignificant change in failure load after five weeks exposure for samples coated by $\mathrm{TiO}_{2}$ was found. For coatings of $\mathrm{Cr}_{2} \mathrm{O}_{3}$ there was a large decreases in the failure load which indicate bond damaging between the adhesive and coated film. Figures 17 and 18 shows a comparison between non-coated reference after air exposure for five weeks with adhesive thickness of 0.005 and 0.01 inch. The decline in the uncoated failure load 
in air was significant, but not as large as the chromate decrease. The data is shown in tables 3 and 5 .

Because the nature of the lap joint allows moisture adsorption through the sides of the specimens, salt deposit trapped between the bonded surface. Rust was found on the specimens surface of the bonded samples after exposure to salt spray, figures 19 and 20, which indicates that corrosion occurred. The location of the corrosion also further indicates that was localized or crevice corrosion. This would clearly identify one cause of the decrease in adhesive failure load with exposure to salt spray to be initiation of crevice corrosion. As the titanate coating showed improved resistance over the chromate to localized corrosion, it can be hypothesized that it was this resistance to localized corrosion that maintained the bond strength for the titanate coating in comparison to the chromate. 


\section{CONCLUSIONS}

A titanate coating provided better durability for adhesive bond strength over a chromate coating on 316L stainless steel after exposure to a marine environment .

The localized corrosion resistance of the titanate compared to the poor resistance chromate in retarding crevice corrosion was thought to be the important factor in increasing bond strength after marine exposure. 


\section{FUTURE WORK}

Applying an interlayer between the substrate and the coating .

Use of the $\mathrm{TiO}_{2}$ instead of $\mathrm{Cr}_{2} \mathrm{O}_{3}$ shows some promise of use in corrosion resistance applications and should be investigated .

Conduct more adhesive bonding testing by examining the effect of adhesive thickness and continue salt spry testing .

Examine the effect of the alternative coating process .

Use more samples of SS316L to identify corrosion effect and testing procedure errors . 


\section{References}

1. Zumdahl, S.S., Chemistry, Pub: D.C. Health and Company, 1989, page 800

2. "Chromic acid, chromates, zinc chromates," http://www.cdc.gov/niosh/pel88/chromic.html. March 12, 2000.

3. Sedriks A.J. and Dudt P.J. , "Corrosion resistance coating, and magnetic property issues of nonmagnetic austenitic stainless steels for ship hull"s Corros. Sci.,V $57, \mathrm{n} 1$, January $2001 "$.

5. Eppensteiner, F.W. \& Jenkins, M.R., "Chromate conversion coatings," Metal Finishing, v. 91, pp. 413-424, January 1993.

6. Fontana, M.G., Corrosion Engineering , pp. 304-315, Pub: McGraw-Hill, Inc., 1986.

7. Hinton, B.R.W., "Corrosion Prevention and Chromates, the End of an Era?" Metal Finishing, v. 89, pp. 55-61, September 1991.

8. Atik .M, Zarzycki .J "Protective $\mathrm{TiO}_{2}-\mathrm{SiO}_{2}$ coatings on stainless steel sheet prepared by dip-coating ", Laboratory of Science of Vitreous Materials (UA 1119),University of Montpellier II, Place E. Bataillon, 34095 Montpellier Cedex 5 , France

9. Leygraf.J ,Thierry.C, Ektessabi.D." Corrosion resistance for biomaterial applications of $\mathrm{TiO}_{2}$ films deposited on titanium and stainless steel by ionassisted sputtering " Journal of Biomedical Materials Research ,Volume, pages: $35,309-318$ ( 1997 )

10. El Basiouny M.S, and Mazhar A.A, "Electrochemical behavior of passive layers on titanium," Corrosion-NACE, vol 38, n5, pp 237-240 (19,82)

11. Hurlen.T and Hornkjol . S, "Anodic growth of passive film on titanium," Electrochim . Acta, vol 36, 189-195 (1991).

12. Clayton . C . R and Olefjord . I ,"Passivity of austenitic stainless steels," in Corrosion Mechanisms in Theory and Practice, P. Marcus and J. Oudar (eds.), Marcel Dekker, New York, 1995, p. 175-199.

13. Hakiki.N.A, Boudin . S, Rondot . B, and Da Cunha Belo.M " The electronic structure of passive films formed on stainless steels," Corros. Sci., V 37, 18091822 (1995). 
14. Pang .M, Eakins D.E, Norton . M .G, and Bahr . D . F, "Structural and mechanical characteristics of anodic oxide films on titanium" Corros. Sci, V 57, No. 6, January 2001"

15. Imokawa, Tooru: Fujisawa, Ryutaro "Protection of 304 stainless steel with $\mathrm{TiO}_{2}$ coating", Corrosion Engineering V 43 :n 9 . Sep 1994

18. David Morgan “Development of Dynamic tensile loading apparatus to determine the strength of Adhesive Joints ", Master Thesis ,University of Rhode Island , 2000

19. Harding, J., 1960, "Tensile Testing of Materials at Impact Rates of Strain," Journal of Mechanical Engineering Science, V. 2, No. 2, pp. 88-96.

20. Nicholas, T., May 1981 "Tensile Testing of Materials at High Rates of Strain," Experimental Mechanics, p. 177-185.

21. Chen, Jia-Yang; Yu, Ge-Ping; Huang, Jia-Hong; "Corrosion behavior and adhesion of ion-plated TiN films, Material chemistry and physics, V 65, p 310-315 ( 2000)

22. L. van Leaven, "Corrosion behavior of ion plated an Implanted Titanium Nitride Films",Master Thesis, University of Rhode Island 1995

23. Taria $Y$, Hai $K$, Matsumora $H$, Atsuta $M$ "Adhesive bonding of Titanium Nitride plated stainless steel for magnetic attachments" European Journal of Oral Sciences V:109 : n3 . Jun $2001:$ pp 204-207

24. American Society for Testing and Materials, Standard Test for Apparent Shear Strength of Single-Lap-Joint Adhesively Boned Metal Specimens by Tension Loading (Metal-to-Metal), Annual Book of ASTM Standards, April 1994, pp.44-47

25. Weiss, $H$ "Adhesion of advanced overlay coatings mechanisms and quantitative assessment" Surface \& Coating Technology : V 71 :No: n2 :Date: Mar, 1995 :p 201-207

26. Kinloch, A. J., Adhesion and Adhesives, Chapman and Hall, New York, 1987.

27. Cagle, C.V., Handbook of Adhesive Bonding, McGraw-Hill Book Co., 1973.

28. Matsumura $H$, Tanoue $N$, Atsuta $M$ "Adhesive bonding of stainless steel and their component metals" Journal of Oral Rehabilitation .V: 27 .n12, Dec 2000 p183-198

29. Broad, Richard; French, John; Sauer, Jochem; "New effective ecological surface pretreatment for highly durable adhesively bonded metal" International journal of adhesion \& adhesives : V: 19 :No: n 2, 1999 : p 193-198 
30 Gaskin, G.B.; Brown, S.R.; "Characterization of stainless steel pretreatments for adhesive bonding" . International SAMPE Technical Conference Oct 21-24 1991 Pages: 739-750

31. EG\&G Princeton Applied Research, "Basics of corrosion measurements", Application Note Corr-1, Prinston., NJ. 1982.

32. EG\&G Princeton Applied Research, "Electrochemistry and corrosion overview and techniques”, Application Note Corr-4, Prinston., NJ. 1982. 
TABLE 1: cyclic polarization characteristics of bare SS 316

\begin{tabular}{|c|c|c|c|c|c|}
\hline $\begin{array}{c}\text { Bare Metal } \\
\text { Non coated }\end{array}$ & $\begin{array}{c}\mathbf{E}_{\text {corr }} \\
(\mathbf{V} \text { vs.SCE })\end{array}$ & $\begin{array}{c}\mathbf{E}_{\text {pp }} \\
(\mathrm{V} \text { vs.SCE })\end{array}$ & $\begin{array}{c}\mathbf{I}_{\text {corr }} \\
\left(\mu \mathrm{A} / \mathrm{cm}^{2}\right)\end{array}$ & $\begin{array}{c}\mathbf{E}_{\mathbf{b}} \\
(\mathbf{V} \text { vs.SEC })\end{array}$ & $\begin{array}{c}\mathbf{I}_{\text {crit }} \\
\left(\mu \mathrm{A} / \mathrm{cm}^{2}\right)\end{array}$ \\
\hline Bare SS 316 & -0.071 & -0.004 & -0.520 & 0.101 & -1.85 \\
\hline
\end{tabular}

TABLE 2 : cyclic polarization characteristics of $\mathrm{TIO}_{2}$ and $\mathrm{Cr}_{2} \mathrm{O}_{3}$ coating

\begin{tabular}{|c|c|c|c|c|c|}
\hline $\begin{array}{c}\text { Metal } \\
\text { coated } \\
\text { with }\end{array}$ & $\begin{array}{c}\mathbf{E}_{\text {corr }} \\
(\mathrm{V} \text { vs.SCE })\end{array}$ & $\begin{array}{c}\mathbf{E}_{\mathrm{p}} \\
(\mathrm{V} \text { vs.SCE })\end{array}$ & $\begin{array}{c}\mathbf{I}_{\text {corr }} \\
\left(\mu \mathrm{A} / \mathrm{cm}^{2}\right)\end{array}$ & $\begin{array}{c}\mathbf{E}_{\mathrm{b}} \\
(\mathbf{V} \text { vs.SCE })\end{array}$ & $\begin{array}{c}\mathbf{I}_{\text {crit }} \\
\left(\mu \mathrm{A} / \mathrm{cm}^{2}\right)\end{array}$ \\
\hline $\mathrm{TiO}_{2}$ & -0.011 & -0.032 & -0.580 & NV & -2.540 \\
\hline $\mathrm{Cr}_{2} \mathrm{O}_{3}$ & 0.039 & -0.042 & -1.301 & 0.126 & -2.688 \\
\hline
\end{tabular}


TABLE 3 : Data characteristics of tensile test for each bonded and coated SS 316L either by Titanium Dioxide or Chromium Trioxide 0.005 inch adhesive thickness )

\begin{tabular}{|c|c|c|c|}
\hline $\begin{array}{c}\text { Time } \\
\text { In weekly } \\
\text { basis }\end{array}$ & $\begin{array}{c}\text { Metal } \\
\text { Coated with }\end{array}$ & Load (Ib) & Average \\
\hline \multirow{2}{*}{$\begin{array}{c}\text { Reference } \\
\text { No salt spray }\end{array}$} & Chromium & $750.221,806.201$ & 778.211 \\
\hline & Titanium & $538.695,526.782$ & 523.738 \\
\hline \multirow{2}{*}{$\begin{array}{l}\text { Week one } \\
\text { (Salt spray) }\end{array}$} & Chromium & $885.328,711.547$ & 798.437 \\
\hline & Titanium & $528.360,533.109$ & 530.735 \\
\hline \multirow{2}{*}{$\begin{array}{c}\text { Week two } \\
\text { (Salt spray) }\end{array}$} & Chromium & $547.782,865.212$ & 706.497 \\
\hline & Titanium & $443.685,680.387$ & 562.036 \\
\hline \multirow{2}{*}{$\begin{array}{l}\text { Week Three } \\
\text { ( salt spray ) }\end{array}$} & Chromium & $455.963,420.213$ & 438.088 \\
\hline & Titanium & $482.374,520.218$ & 501.296 \\
\hline \multirow{2}{*}{$\begin{array}{l}\text { Week Four } \\
\text { ( salt spray ) }\end{array}$} & Chromium & $500.717,321.2011$ & 410.959 \\
\hline & Titanium & $414.113,420.179$ & 417.146 \\
\hline \multirow{2}{*}{$\begin{array}{l}\text { Week Five } \\
\text { ( salt spray ) }\end{array}$} & Chromium & $303.074,301.742$ & 302.408 \\
\hline & Titanium & $370.739,323.154$ & 346.946 \\
\hline \multirow{2}{*}{$\begin{array}{r}\text { Week Five } \\
\text { No salt spray }\end{array}$} & Chromium & $585.214,540.141$ & 562.677 \\
\hline & Titanium & $540.792,607.288$ & 574.04 \\
\hline
\end{tabular}

TABLE 4 : Data characteristics of tensile test for bonded and non coated SS 316L ( 0.005 adhesive thickness)

\begin{tabular}{|c|c|c|}
\hline Time (weekly) & Load ( Ib) & Average \\
\hline Reference & $650.354,540.320$ & 595.337 \\
\hline Week Five & $454.201,540.231$ & 542.716 \\
\hline
\end{tabular}


TABLE 5: Data characteristics of tensile test for each bonded and coated SS 316L either by Titanium Dioxide or Chromium Trioxide (0.01 inch adhesive thickness ):

\begin{tabular}{|c|c|c|c|}
\hline $\begin{array}{c}\text { Time } \\
\text { In weekly basis }\end{array}$ & $\begin{array}{c}\text { Metal } \\
\text { Coated with }\end{array}$ & Load (Ib) & Average \\
\hline \multirow{2}{*}{$\begin{array}{r}\text { Reference } \\
\text { (No salt spray) }\end{array}$} & Chromium & 730.542 & 730.542 \\
\hline & Titanium & 511.891 & 511.891 \\
\hline \multirow{2}{*}{$\begin{array}{l}\text { Week one } \\
\text { (Salt spray) }\end{array}$} & Chromium & 557.152 & 557.152 \\
\hline & Titanium & 443.666 & 443.666 \\
\hline \multirow{2}{*}{$\begin{array}{l}\text { Week two } \\
\text { (Salt spray) }\end{array}$} & Chromium & 507.114 & 507.114 \\
\hline & Titanium & 411.061 & 411.061 \\
\hline \multirow{2}{*}{$\begin{array}{l}\text { Week Three } \\
\text { ( salt spray ) }\end{array}$} & Chromium & 248.998 & 248.998 \\
\hline & Titanium & 421.586 & 421.586 \\
\hline \multirow{2}{*}{$\begin{array}{l}\text { Week Four } \\
\text { ( salt spray ) }\end{array}$} & Chromium & 213.149 & 231.149 \\
\hline & Titanium & 400.192 & 400.192 \\
\hline \multirow{2}{*}{$\begin{array}{l}\text { Week Five } \\
\text { ( salt spray ) }\end{array}$} & Chromium & 213.866 & 213.866 \\
\hline & Titanium & 275.326 & 275.326 \\
\hline \multirow{2}{*}{$\begin{array}{r}\text { Week Five } \\
\text { ( No salt } \\
\text { spray) }\end{array}$} & Chromium & 460.810 & 460.810 \\
\hline & Titanium & 469.503 & 469.503 \\
\hline
\end{tabular}

TABLE 6: Data characteristics of tensile test for bonded and non coated SS 316L( 0.01 inch adhesive thickness ):

\begin{tabular}{|c|c|c|}
\hline Time (weekly) & Load ( Ib) & Average \\
\hline Reference & 512.612 & 512.612 \\
\hline Week Five & 454.201 & 454.201 \\
\hline
\end{tabular}


FIGURES

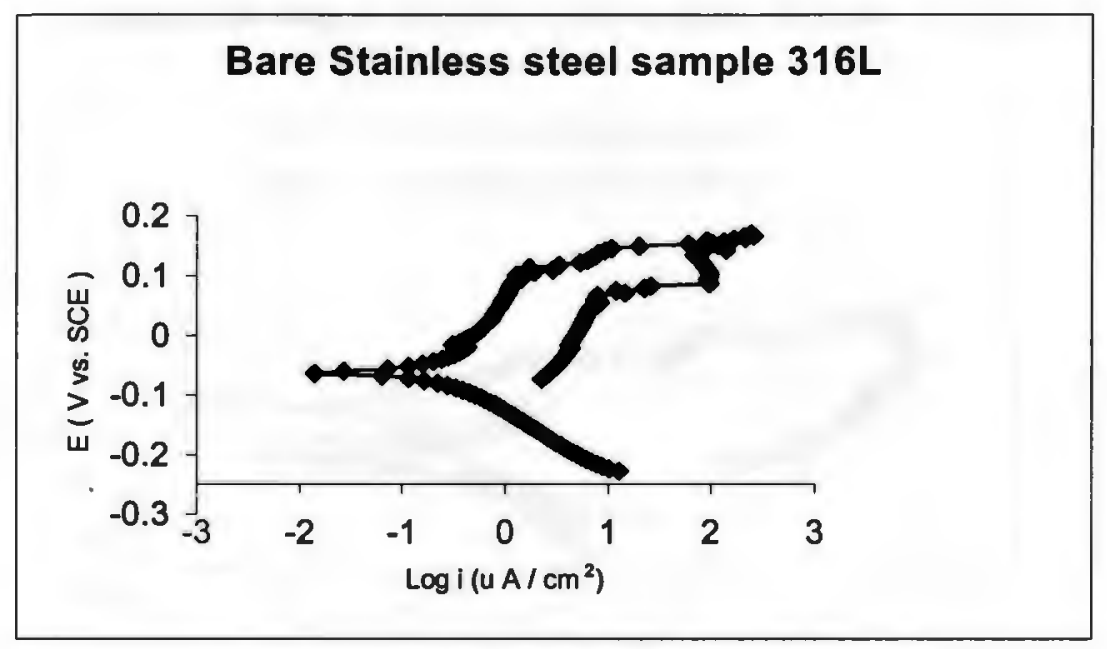

Figure 1. Potentiodynamic polarization curve for uncoated 316L and exposed to deaerated $0.5 \mathrm{M} \mathrm{NaCL}$ solution. 


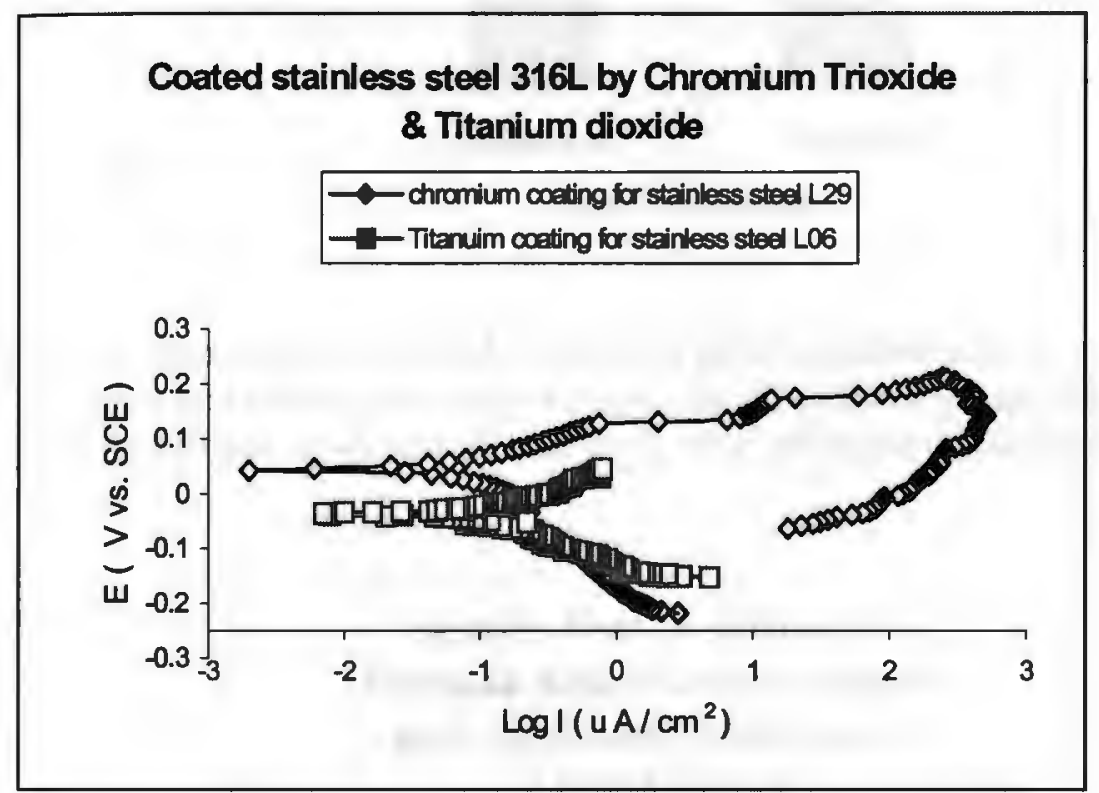

Figure 2. Potentiodynamic polarization curve for $316 \mathrm{~L}$ stainless steel coated by chromium trioxide and titanium dioxide exposed to de-aerated $0.05 \mathrm{M} \mathrm{NaCl}$ solution . 


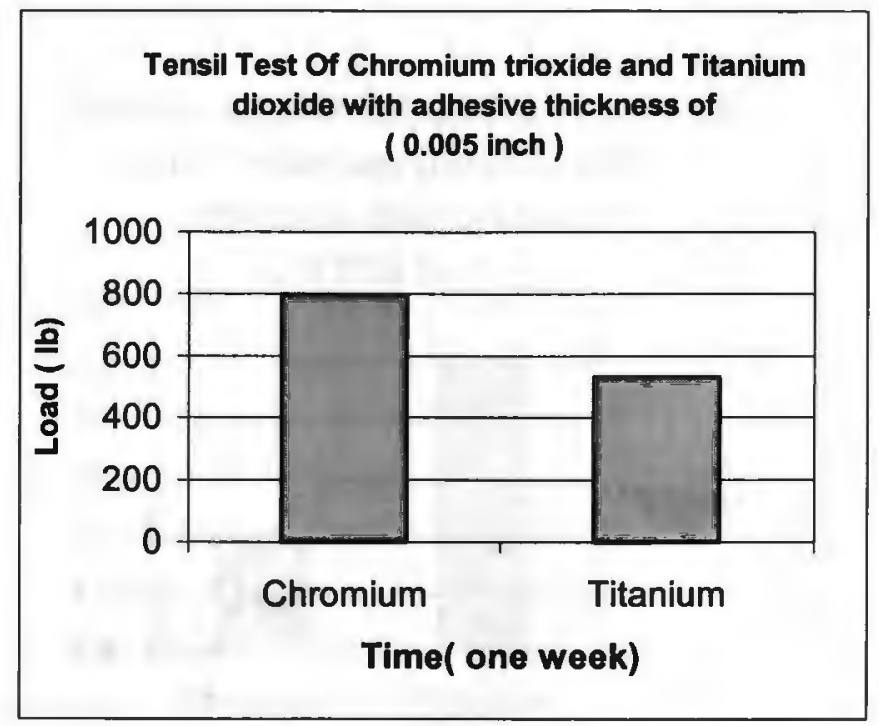

Figure 3. Comparison of failure load for the two pairs of chromium trioxide coated samples and another two pairs of titanium dioxide coated samples that were exposed to salt spray test for one week with adhesive thickness of 0.005 inch.

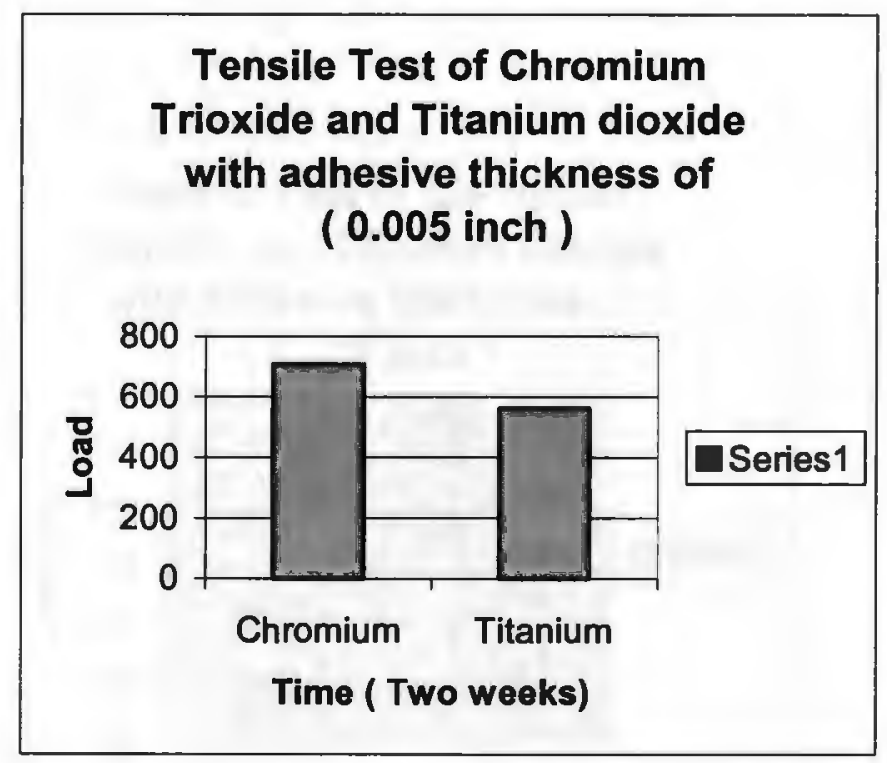

Figure 4 Comparison of failure load for the two pairs of chromium trioxide coated samples and another two pairs of titanium dioxide coated samples that were exposed to salt spray test for two week with adhesive thickness of 0.005 inch 


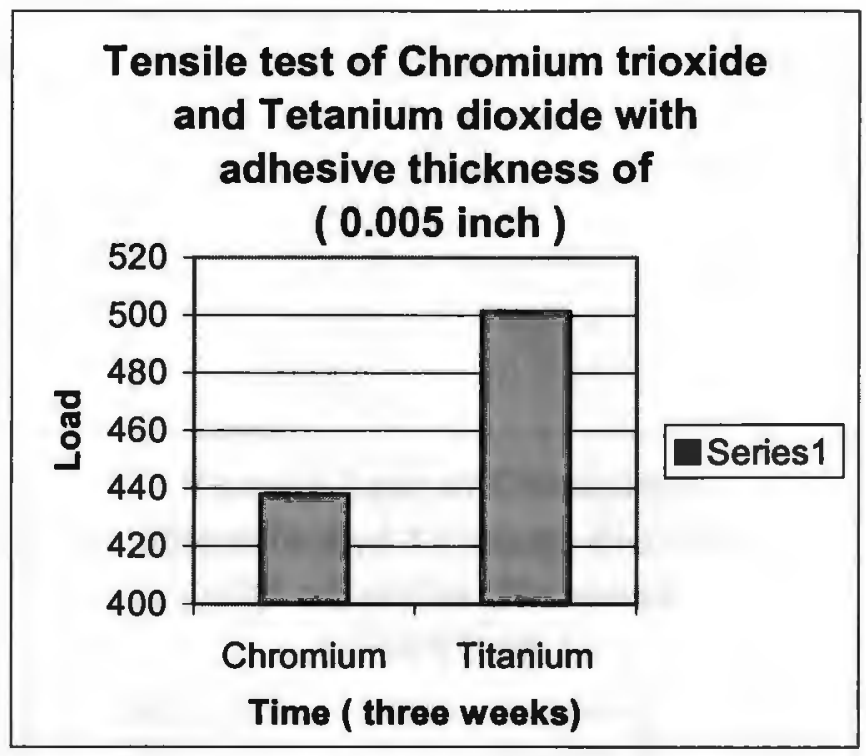

Figure 5 Comparison of failure load for the two pairs of chromium trioxide coated samples and another two pairs of titanium dioxide coated samples that were exposed to salt spray test for three weeks with adhesive thickness of 0.005 inch .

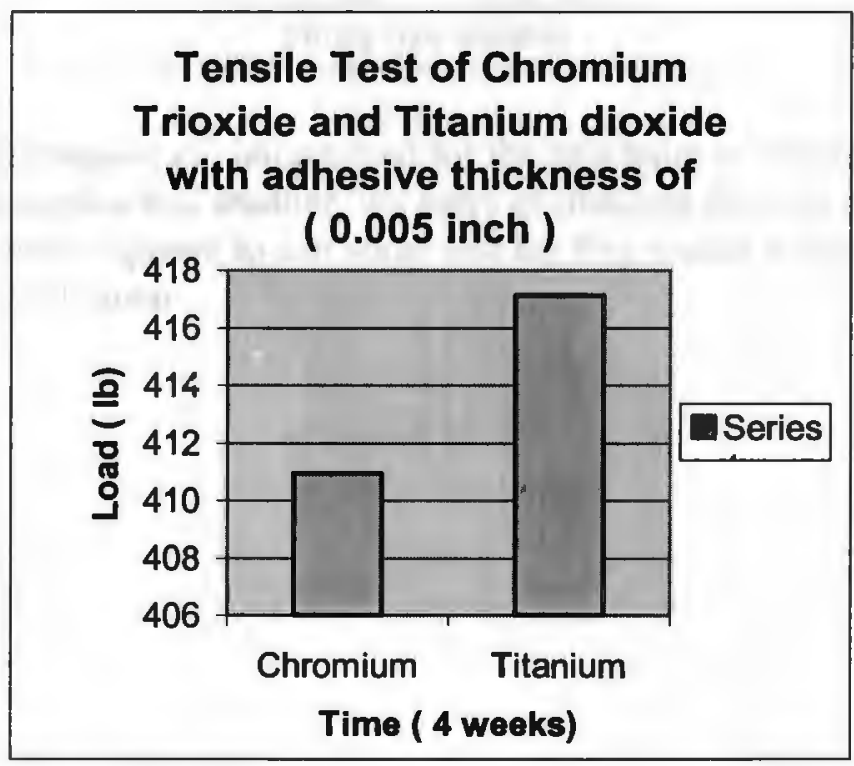

Figure 6 Comparison of failure load for the two pairs of chromium trioxide coated samples and another two pairs of titanium dioxide coated samples that were exposed to salt spray test for four weeks with adhesive thickness of 0.005 inch 


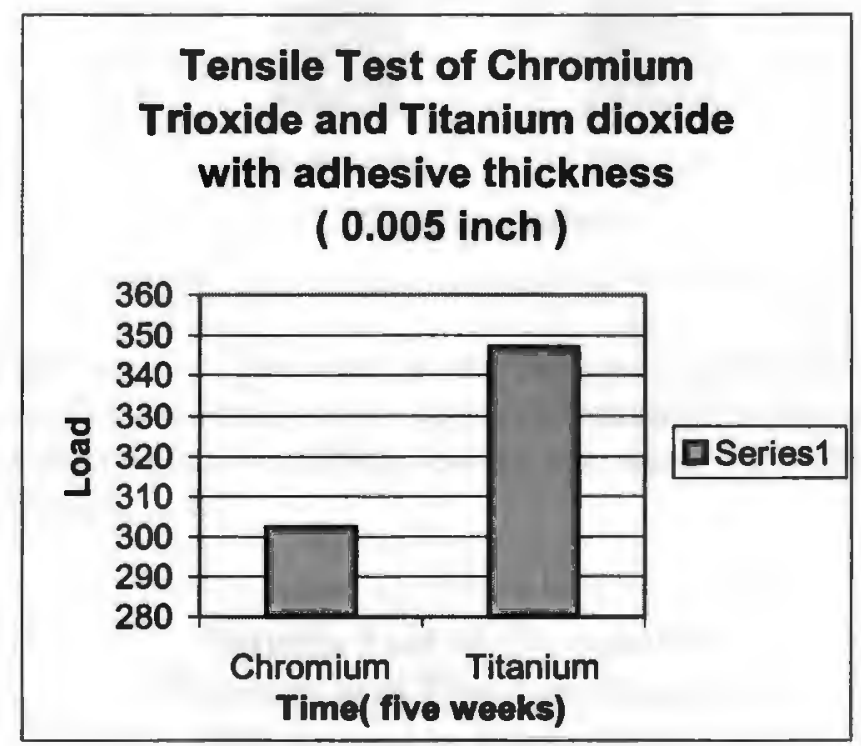

Figure 7 Comparison of failure load for the two pairs of chromium trioxide coated samples and another two pairs of titanium dioxide coated samples that were exposed to salt spray test for five weeks with adhesive thickness of 0.005 inch . 


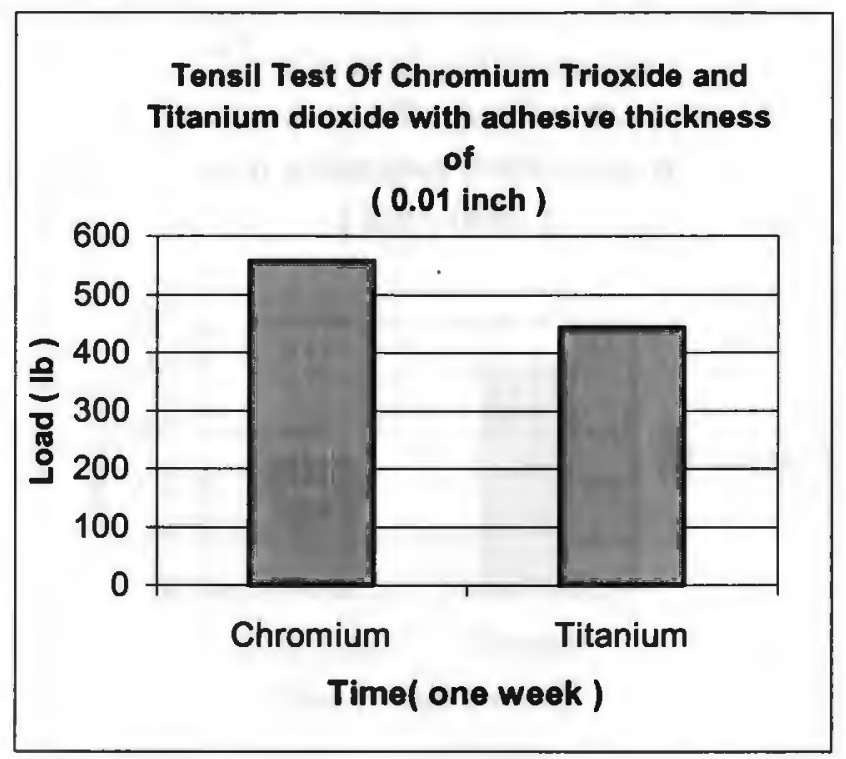

Figure 8 Comparison of failure load for the two pairs of chromium trioxide coated samples and another two pairs of titanium dioxide coated samples that wereexposed to salt spray test for one week with adhesive thickness of 0.01 inch.

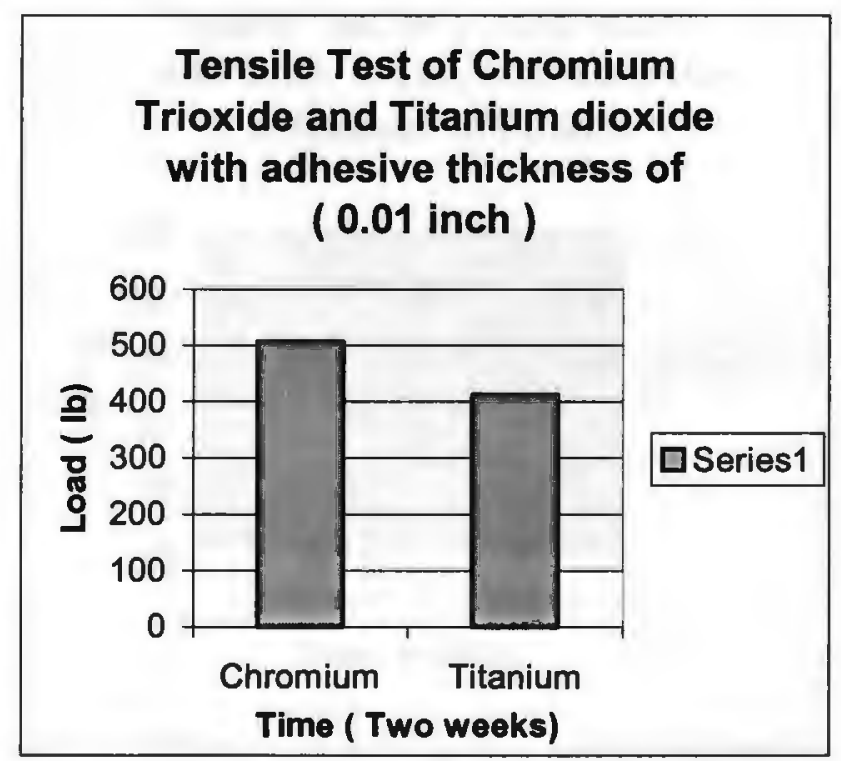

Figure 9 Comparison of failure load for the two pairs of chromium trioxide coated samples and another two pairs of titanium dioxide coated samples that were exposed to salt spray test for two weeks with adhesive thickness of 0.01 inch. 


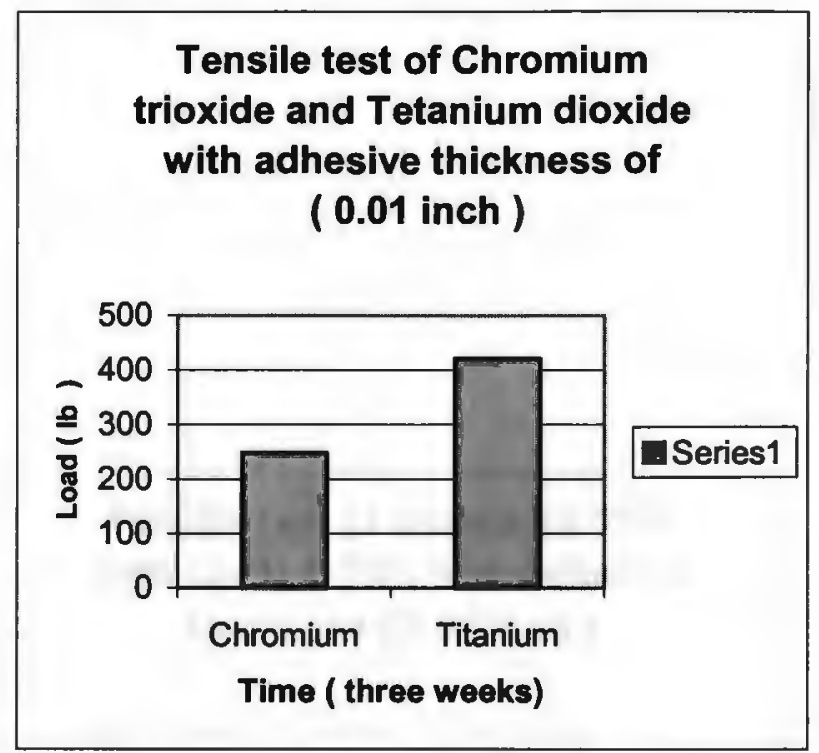

Figure 10 Comparison of failure load for the two pairs of chromium trioxide coated samples and another two pairs of titanium dioxide coated samples that were exposed to salt spray test for three weeks with adhesive thickness of 0.01 inch .

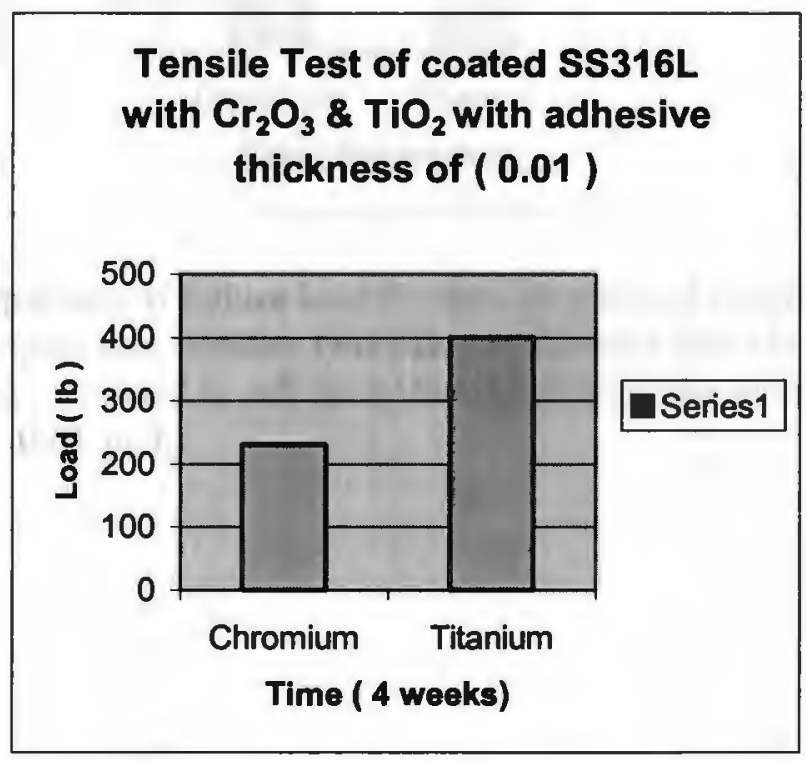

Figure 11 Comparison of failure load for the two pairs of chromium trioxide coated samples and another two pairs of titanium dioxide coated samples that were exposed to salt spray test for four weeks with adhesive thickness of 0.01 inch . 


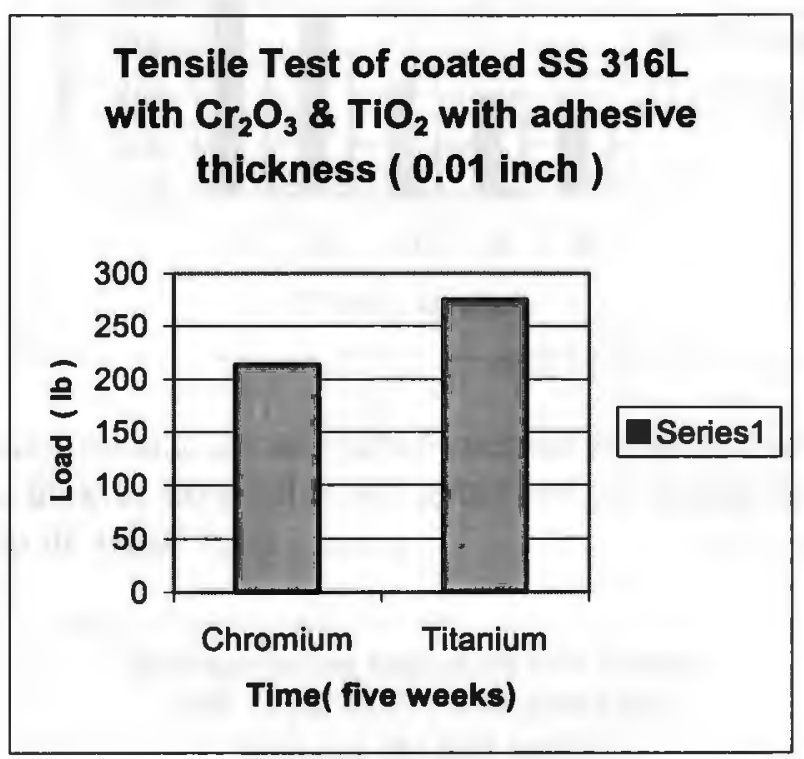

Figure 12. Comparison of failure load for the two pairs of chromium trioxide coated samples and another two pairs of titanium dioxide coated samples that were exposed to salt spray test for five weeks with adhesive thickness of 0.01 inch. 


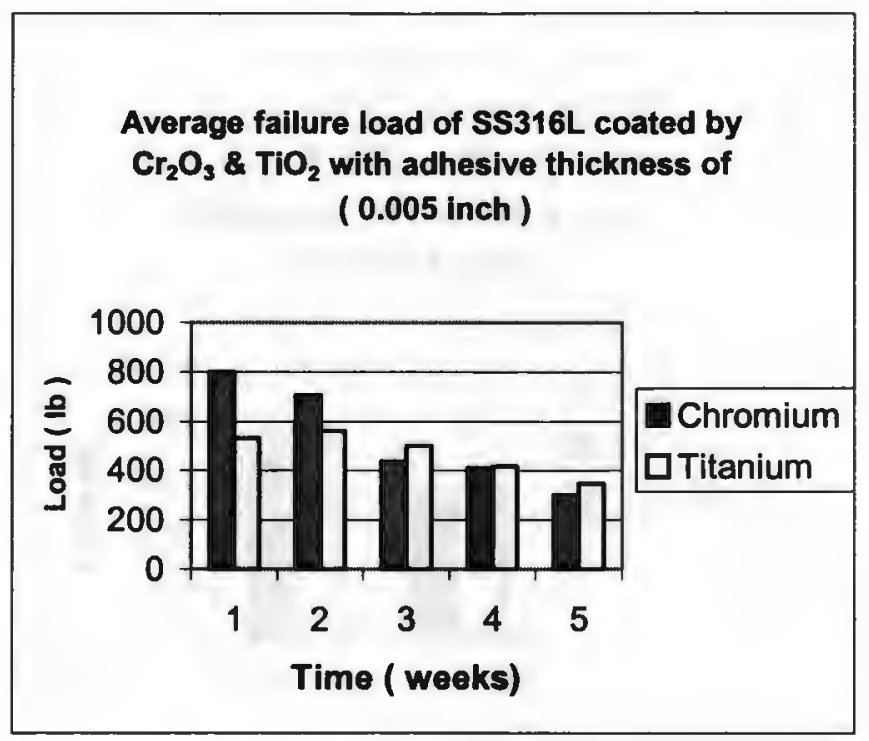

Figure 13 Average failure load for all coated samples either by trioxide chromium or titanium dioxide exposed to salt spray test on weekly bases with adhesive thickness of 0.005 inch.

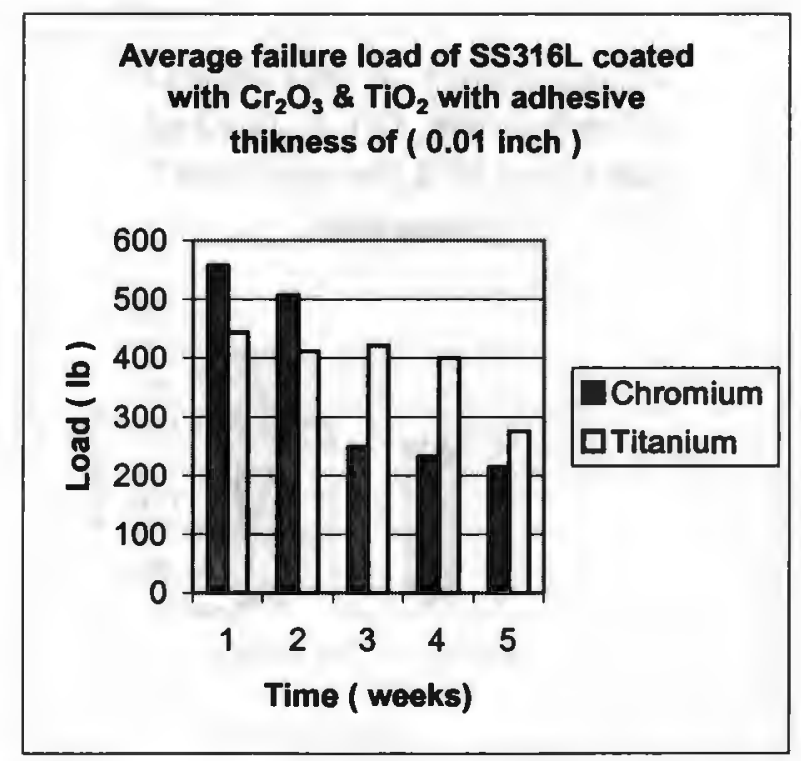

Figure 14 Average failure load for all coated samples either by chromium trioxide or titanium dioxide exposed to salt spray test on weekly bases with adhesive thickness of 0.01 inch . 


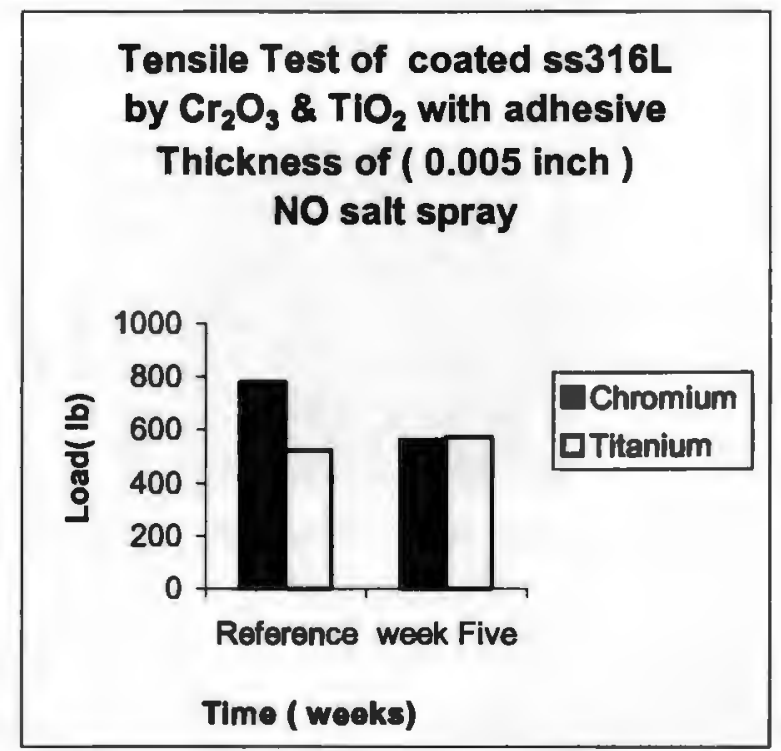

Figure 15. Comparison of failure load between uncoated reference samples after air exposure for five weeks then, with adhesive thickness of 0.005 inch .

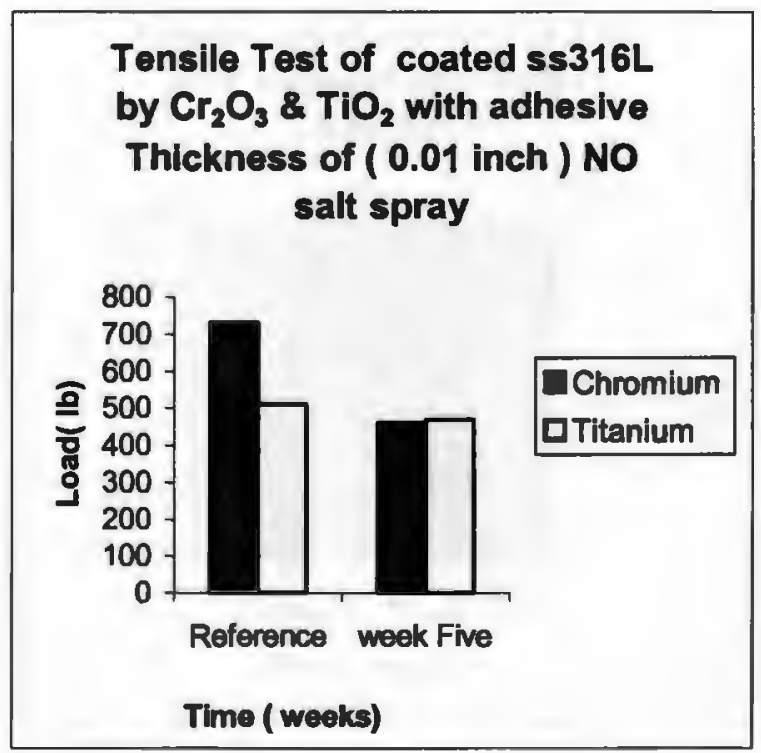

Figure 16. Comparison of failure load between uncoated reference samples after air exposure for five weeks, adhesive thickness of $0.01 \mathrm{inch}$. 


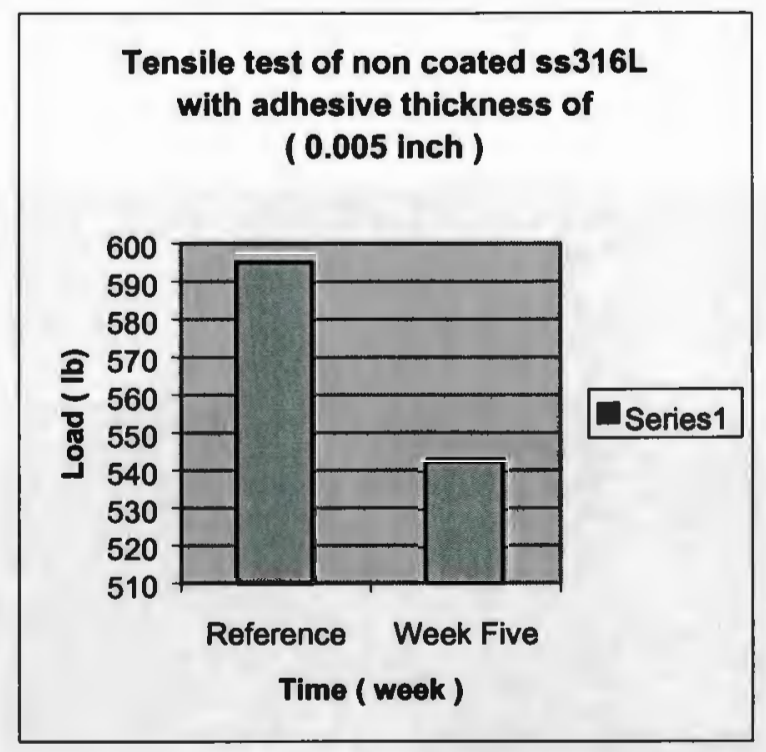

Figures 17. A comparison of failure load for non coated 316L samples after air exposure for 5 weeks, 0.005 inch adhesive thickness.

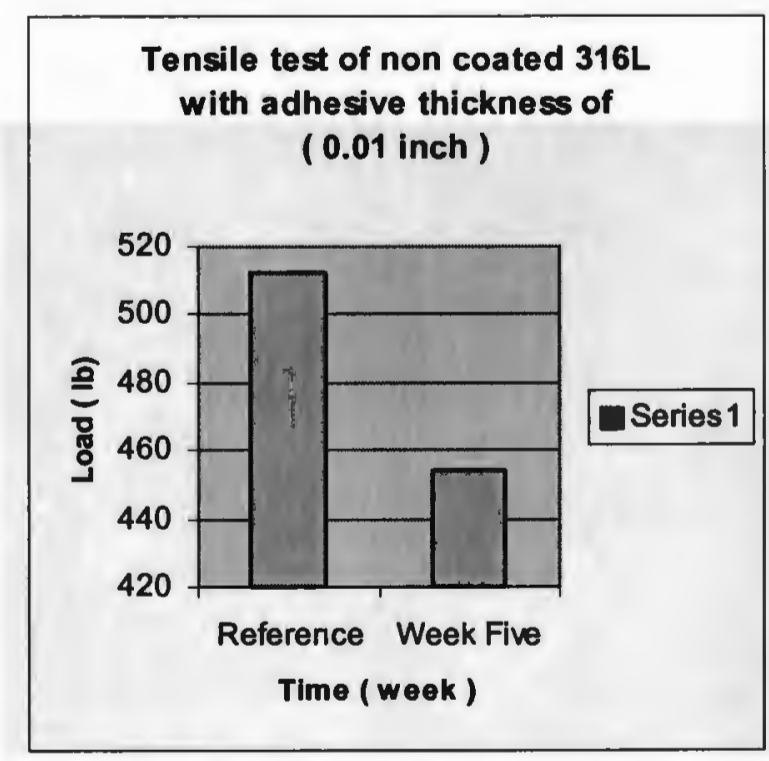

Figures 18. A comparison of failure load for non coated 316L samples after air exposure for 5 weeks, 0.01 inch adhesive thickness. 


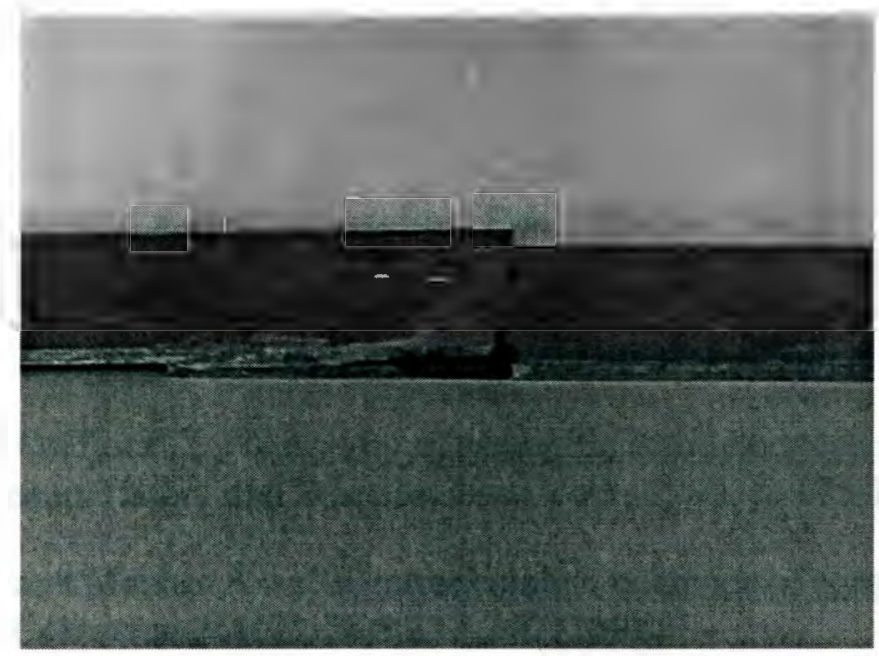

Figure 19 Corrosion on the chromate sample took place after 5 weeks exposure to salt spray

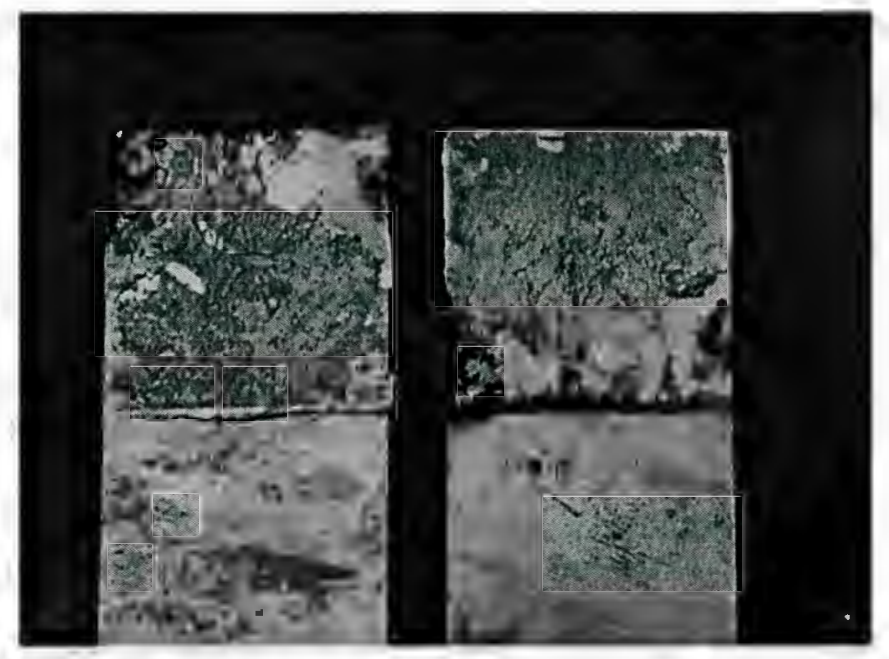

Figure 20. Crevice corrosion on 316L. 


\section{BIBLOIGRAPHY}

Cagle, C.V., Handbook of Adhesive Bonding, Pub, McGraw-Hill Book Co., 1973.

Chen, Jia-Yang; Yu, Ge-Ping; Huang, Jia-Hong; "Corrosion behavior and adhesion of ion-plated TiN films" Material chemistry and physics, V65, p 310-315, 2000

Clayton .C.R and Olefjord . I , "Passivity of austenitic stainless steels," Corrosion Mechanisms in Theory and Practice, New York, 1995, p. 175-199.

El Basiouny M.S, and Mazhar A.A, "Electrochemical behavior of passive layers on titanium," Corrosion-NACE, 38,5,237-240 (1982)

Eppensteiner, F.W. \& Jenkins, M.R., "Chromate Conversion Coatings," Metal Finishing, V. 91, p. 413-424, January 1993

Fontana, M.G., Corrosion Engineering, p. 304-315, pub McGraw-Hill, Inc., 1986

Hakiki.N.A, Boudin . S, Rondot . B, and Da Cunha Belo.M , "The electronic structure of passive films formed on stainless steels "Corros. Sci., 37, 1809-1822 (1995).

Harding, J., 1960, "Tensile Testing of Materials at Impact Rates of Strain," Journal of Mechanical Engineering Science, V. 2, No. 2, pp. 88-96.

Hinton, B.R.W., "Corrosion Prevention and Chromates, the End of an Era?" Metal Finishing, V. 89, p. 55-61, September 1991.

Hurlen.T and Hornkjol .S, "Anodic growth of passive film on titanium," Electrochim . Acta, 36, 189-195 (1991).

Imokawa, Tooru: Fujisawa, Ryutaro "Protection of 304 stainless steel with $\mathrm{TiO}_{2}$ coating", Corrosion Engineering V 43 : n9 :Sep 1994

Kinloch, A. J., Adhesion and Adhesives, Chapman and Hall, New York, 198

Nicholas, T., May 1981 "Tensile Testing of Materials at High Rates of Strain," Experimental Mechanics, p. 177-185. 
Taria Y, Hai K, Matsumora H, Atsuta M "Adhesive bonding of Titanium Nitride plated stainless steel for magnetic attachments" European Journal of Oral Sciences Vol: 109 :No 3 , Date: jun 2001 :p: 204-207 